\title{
Onset of pup locomotion coincides with loss of NR2C/D-mediated cortico-striatal EPSCs and dampening of striatal network immature activity
}

\section{Nathalie Dehorter ${ }^{1,2,3}$, François J. Michel ${ }^{1,2,3}$,Thomas Marissal ${ }^{1,2,3}$, Yann Rotrou ${ }^{4,5}$, Boris Matrot ${ }^{4,5}$, Catherine Lopez ${ }^{1,2,3}$, Mark D. Humphries ${ }^{6}$ and Constance Hammond ${ }^{1,2,3}$ *}

1 INSERM Unité 901, Marseille, France

2 UMR S901 Aix-Marseille 2, Université de la Méditerranée, Marseille, France

${ }^{3}$ INMD, Marseille, France

4 INSERM Unité 676, Hôpital Robert Debré, Paris, France

${ }^{5}$ Université Paris Diderot, Paris, France

${ }^{6}$ Laboratoire de Neurosciences Cognitives, INSERM Unité 960, Ecole Normale Supérieure, Paris, France

\section{Edited by:}

Enrico Cherubini, International School for Advanced Studies, Italy

\section{Reviewed by:}

Enrico Bracci, University of

Manchester, UK

Paolo Calabresi, Santa Maria Della

Misericordia Hospital, Italy

\section{*Correspondence:}

Constance Hammond, Institut de Neurobiologie de la Méditerranée, INSERM UMR 901, 163 route de Luminy, BP13, 13273 Marseille Cédex 9, France.

e-mail: hammond@inmed.univ-mrs.fr
Adult motor coordination requires strong coincident cortical excitatory input to hyperpolarized medium spiny neurons (MSNs), the dominant neuronal population of the striatum. However, cortical and subcortical neurons generate during development large ongoing patterns required for activity-dependent construction of networks. This raises the question of whether immature MSNs have adult features from early stages or whether they generate immature patterns that are timely silenced to enable locomotion. Using a wide range of techniques including dynamic two-photon imaging, whole cell or single-channel patch clamp recording in slices from Nkx2.1-GFP mice, we now report a silencing of MSNs that timely coincides with locomotion. At embryonic stage (as early as E16) and during early postnatal days, genetically identified MSNs have a depolarized resting membrane potential, a high input resistance and lack both inward rectifying $\left(\mathrm{IK}_{\mathrm{IR}}\right)$ and early slowly inactivating $\left(I_{D}\right)$ potassium currents. They generate intrinsic voltage-gated clustered calcium activity without synaptic components. From postnatal days 5-7, the striatal network transiently generates synapse-driven giant depolarizing potentials when activation of cortical inputs evokes long lasting EPSCs in MSNs. Both are mediated by NR2C/D-receptors. These immature features are abruptly replaced by adult ones before P10: MSNs express IKIR and $I_{D}$ and generate short lasting, time-locked cortico-striatal AMPA/NMDA EPSCs with no NR2C/D component. This shift parallels the onset of quadruped motion by the pup. Therefore, MSNs generate immature patterns that are timely shut off to enable the coordination of motor programs.

Keywords: development, basal ganglia, striatum, immature activity, locomotion, patch clamp, two-photons imaging, mouse pup

\section{INTRODUCTION}

Adult medium spiny neurons (MSNs), the GABAergic principal neurons of the striatum, have unique features required for the appropriate selection of motor programs (Grillner et al., 2005). They are highly hyperpolarized at rest and require strong coincident excitatory glutamatergic inputs for the execution of appropriate movements (Wilson and Kawaguchi, 1996). These unique features are due to strong inward rectifying $\left(I \mathrm{~K}_{\mathrm{IR}}\right)$ and slow inactivating $\left(I_{\mathrm{D}}\right)$ potassium currents and feedforward and feedback afferent inhibition that confer a low input resistance, hyperpolarized resting potential, and a long delay to initial spiking (Tepper et al., 2004). In a large range of animal species and brain structures, immature neurons are highly excitable and developing networks generate network-driven patterns that are instrumental in neuronal growth, synapse formation, and the formation of functional circuits (for review Ben-Ari, 2002; Spitzer, 2006; Huberman et al., 2008; Blankenship and Feller, 2010). These observations raise the question whether MSNs differ from other neuronal types and are silent from early developmental stages and if not when and how are the early patterns switched off to enable correct motor coordination and quadruped motion.

Medium spiny neurons originate in the lateral ganglionic eminence (Deacon et al., 1994; Olsson et al., 1998) and migrate radially into the developing striatum compartments (Van Der Kooy and Fishell, 1987). To understand MSN functional maturation, we targeted embryonic and early postnatal MSNs with the use of Nk2 homeobox 1 (Nkx2.1)-GFP Mice. Nkx2.1, also known as thyroid transcription factor-1 (TTF-1), is a protein that regulates transcription of genes and is specifically expressed by interneurons but not by MSNs in the striatum (Nobrega-Pereira et al., 2008). We determined MSNs' cellular properties using whole cell and single-channel recordings. In parallel we performed two-photon dynamic imaging that enables to determine the activity of large neuronal samples in slice preparation (Crepel et al., 2007). We 
then used behavioral analysis to describe posture and onset of locomotion in newborn pups. We report an abrupt switch of cellular and synaptic properties in MSNs in parallel with the initiation of locomotion.

\section{MATERIALS AND METHODS EMBRYONIC AND POSTNATAL SLICE PREPARATIONS}

We performed experiments in embryonic (E14, E16, E18) or postnatal (P0-P45) wild type C57BL/6 mice (Janvier, France) or Nkx2.1-GFP mice of either sex obtained by crossing Nkx2.1-CRE C57BL/6 mice (Jackson lab) and the RCE:LoxP reporter strain (Sousa et al., 2009). We anesthetized pregnant mice with xylazine (Rompun 2\%; used at 0.05\%) and ketamine (Imalgene 1000; used at $50 \mathrm{~g} / \mathrm{l}$; Volume injected: $0.2 \mathrm{ml} / \mathrm{g}$ ) and postnatal mice with isoflurane. We kept brains in ice-cold oxygenated solution containing (in mM): 110 choline, $2.5 \mathrm{KCl}, 1.25 \mathrm{NaH}_{2} \mathrm{PO}_{4}, 7 \mathrm{MgCl}_{2}, 0.5$ $\mathrm{CaCl}_{2}, 25 \mathrm{NaHCO}_{3}, 7$ glucose, and performed coronal, parasagittal, or horizontal slices ( $400 \mu \mathrm{m}$ thick) using a vibratome (VT1200 Leica Microsystems Germany). During the recovery period, slices were placed at room temperature (RT) with standard artificial cerebrospinal fluid (ACSF) saturated with 95\% $\mathrm{O}_{2} / 5 \% \mathrm{CO}_{2}$ and containing (in $\mathrm{mM}$ ): $126 \mathrm{NaCl}, 3.5 \mathrm{KCl}, 1.2 \mathrm{NaH}_{2} \mathrm{PO}_{4}, 1.3 \mathrm{MgCl}_{2}$, $2 \mathrm{CaCl}_{2}, 25 \mathrm{NaHCO}_{3}, 11$ glucose.

\section{CALCIUM IMAGING}

Slices were incubated for $30 \mathrm{~min}$ in $2.5 \mathrm{ml}$ of oxygenated ACSF (35$\left.37^{\circ} \mathrm{C}\right)$ with $25 \mu \mathrm{l}$ fura $2 \mathrm{AM}(1 \mathrm{mM}$, in $\mathrm{DMSO}+0.8 \%$ pluronic acid; Molecular Probes). Imaging was performed with a multibeam two-photon laser scanning system (Trimscope-LaVision Biotec) coupled to an Olympus microscope with a high numerical aperture objective $(20 \times$, NA 0.95 , Olympus). Images of the scan field $(444 \mu \mathrm{m} \times 336 \mu \mathrm{m})$ were acquired via a CCD camera $(4 \times 4$ binning; La Vision Imager $3 \mathrm{QE}$ ) with a time resolution of 115$147 \mathrm{~ms}$ (non-ratiometric 1000-3000 images, laser at $780 \mathrm{~nm}$ ) as previously described (Crepel et al., 2007). In slices from Nkx2.1GFP mice, we first took images of the GFP-expressing neurons (laser at $910 \mathrm{~nm}$ ) before acquiring spontaneous fura 2 fluorescence changes (laser at $780 \mathrm{~nm}$ ). To patch clamp record particular neurons Fura pentapotassium salt ( $30 \mu \mathrm{M}$; Invitrogen) was added to the pipette solution to keep cells fluorescent.

\section{PATCH CLAMP RECORDINGS}

Cells were visualized with infrared-differential interference optics (Axioskop2; Zeiss). We performed recordings at $35-37^{\circ} \mathrm{C}$. For current clamp recordings, the pipette contained (in $\mathrm{mM}$ ): 15 $\mathrm{KCl}, 5 \mathrm{NaCl}, 125 \mathrm{KMeSO}_{4}, 10 \mathrm{HEPES}, 2.5 \mathrm{Mg}$-ATP, $0.3 \mathrm{Na}-$ GTP. For whole cell voltage-clamp recordings of postsynaptic $\mathrm{GABA}_{\mathrm{A}}$ (sIPSCs) and glutamatergic (sEPSCs) currents, the pipette (6-10 M $\Omega$ ) contained (in $\mathrm{mM}$ ): $120 \mathrm{Cs}$-gluconate, $13 \mathrm{CsCl}, 1$ $\mathrm{CaCl}_{2}, 10$ HEPES, 10 EGTA, pH 7.2-7.4 (275-285 mOsm). We recorded sIPSCs at the reversal potential of sEPSCs $(+10 \mathrm{mV})$. To record sEPSCs we continuously applied a $\mathrm{GABA}_{\mathrm{A}}$ receptor antagonist (bicuculline $20 \mu \mathrm{M}$ or Gabazine $5 \mu \mathrm{M}$ ), and maintained the membrane potential at -80 or $+40 \mathrm{mV}$ to separately detect AMPA/kainate (KA) and NMDA sEPSCs, respectively (Groc et al., 2002). We recorded AMPA/KA sEPSCs in the continuous presence of APV $(40 \mu \mathrm{M})$, the selective NMDA receptor antagonist, and separated AMPA from KA sEPSCs by applying NBQX at a dose $(1 \mu \mathrm{M})$ that preferentially blocks AMPA receptors. We identified NMDA sEPSCs at $+40 \mathrm{mV}$ by their kinetics (the NMDA decay time is longer than the AMPA one) or insensitivity to the AMPA/KA receptor antagonist, NBQX $(10 \mu \mathrm{M})$.

To record unitary $\mathrm{GABA}_{\mathrm{A}}$ currents the pipette (4-5 M $\Omega$ ) contained (in $\mathrm{mM}$ ): $120 \mathrm{NaCl}, 20 \mathrm{TEA}-\mathrm{Cl}$ (tetraethylammonium chloride), $5 \mathrm{KCl}, 5$-aminopyridine, $0.1 \mathrm{CaCl}_{2}, 10 \mathrm{MgCl}_{2}, 10$ glucose, 5 GABA, 5 isoguvacine, $3 \mathrm{CsCl}, 10$ HEPES-NaOH buffered to pH 7.2-7.3; osmolality of 300-320 mOsm. When Gabazine $10 \mu \mathrm{M}$ was added to the above pipette solution no unitary currents were recorded. To record unitary NMDA currents, the pipette (4-5 M $\Omega$ ) contained (in mM): $140 \mathrm{NaCl}, 3.5 \mathrm{KCl}, 1.8 \mathrm{CaCl}_{2}, 10 \mathrm{HEPES}$, 10 NMDA, 10 glycine, 1 strychnine, buffered to $\mathrm{pH} 7.43$; osmolality of 300-320 mOsm. When APV $(40 \mu \mathrm{M})$ was added to the pipette solution, no unitary currents were recorded. To identify the morphology of neurons recorded in cell-attached configuration, we re-patched them with a conventional whole cell electrode containing neurobiotin (Abcys).

\section{IDENTIFICATION OF IMMATURE MSNs VS. INTERNEURONS OR VS. ASTROCYTES}

Since embryonic and early postnatal MSNs lack their characteristic adult $\mathrm{K}^{+}$currents, they could not be identified from their electrophysiological properties. We therefore identified them as GFP-negative neurons (Sousa et al., 2009) in striatal slices from Nkx2.1-GFP mice. To quantify the proportion of Nkx2.1positive striatal interneurons that faintly expressed GFP and were therefore considered as MSNs, we performed immunocytochemistry of Nkx2.1 (see below; Figure 1A). From a total of 2767 Nkx2.1-expressing striatal neurons labeled with TTF-1 (red), $75 \%$ were also GFP positive (yellow, $n=2077$ ), showing that in perinatal slices from Nkx2.1-GFP mice, $25 \%$ of the Nkx2.1positive neurons, though GFP-negative, were not MSNs. In our two-photon recordings, GFP positive/fura 2-loaded neurons represented $10-20 \%$ of all fura 2-loaded cells. Therefore instead of $10-20 \%$ interneurons, we had around $13-27 \%$ interneurons in the field. We thus overestimated the proportion of MSNs by $3-7 \%$.

To quantify the proportion of fura 2-loaded cells that were astrocytes and not neurons in slices from P10 to P12 mice, and could be erroneously considered as silent neurons, we performed double loading of slices with sulforhodamine 101 (SR101, $1 \mu \mathrm{M}$ ), a specific marker of astroglia (Nimmerjahn et al., 2004) during $20 \mathrm{~min}$ at $35-37^{\circ} \mathrm{C}$ and then with fura $2 \mathrm{AM}$ (Figure 1B). At P12, astrocytes represented around $25 \%$ of all the imaged cells ( $n=201 / 815$ from five slices). Among these astrocytes, around $40 \%$ were also positive for fura $2(n=86 / 201)$. Therefore around $10 \%$ of fura 2 -loaded cells were astrocytes $(n=86 / 815)$. All these fura 2-loaded astrocytes were silent and could be erroneously counted as silent neurons.

\section{IMMUNOCYTOCHEMISTRY AND Dil EXPERIMENTS}

To reveal the neurobiotin injected during whole cell recordings, the sections were left $12 \mathrm{~h}$ in paraformaldehyde $(3 \%)$ at $4^{\circ} \mathrm{C}$, rinsed in PBS, left $12 \mathrm{~h}$ in PB-sucrose $20 \%$, and then at $-80^{\circ} \mathrm{C}$ for at least $2 \mathrm{~h}$. They were thawed at RT, rinsed in $\mathrm{PB}$ and incubated 


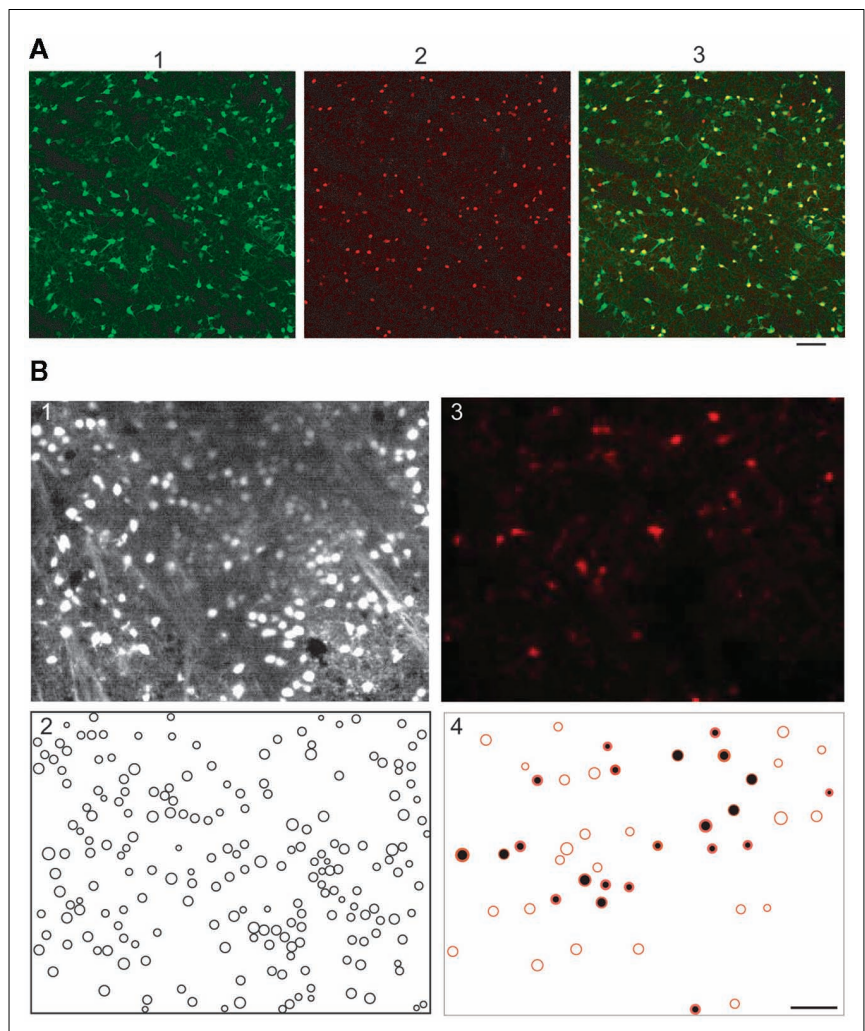

FIGURE 1 | Quantification of percent of GFP-negative/Nkx2.1-positive neuron in perinatal striatal slices and of percent of fura 2-loaded astrocytes in the P10-P12 striatal slices. (A1) Confocal image of the GFP-expressing neurons in the dorso-lateral region of the striatum (slice from a P2 Nkx2.1-GFP mouse). (A2) Nkx2.1-expressing neurons in the same field revealed with the TTF-1/111-121 antibody (in red, see Materials and Methods). (A3) The superimposition of the two images shows that of the $161 \mathrm{Nkx}$ 2.1-expressing neurons 13 were GFP-negative meaning that in this field 13 striatal interneurons out of 161 could be erroneously considered as MSNs. (B) Two-photon images of a striatal slice first loaded with sulforhodamine 101 (SR101, $1 \mu \mathrm{M}$ ) and then with fura 2AM. (B1) Fura 2 fluorescent cells $(n=196)$ imaged with excitation wavelength and emission filter parameters specific for fura 2 (laser at $780 \mathrm{~nm}$ and emission filter $535 \pm 25 \mathrm{~nm}$, parameters that give no images of cells loaded with SR101 only). (B2) Manually detected contours of the cells from the fluorescence images ( $n=196$ fura 2-loaded cells). (B3) SR101 fluorescent astrocytes $(n=46)$ imaged with excitation wavelength and emission filter parameters adjusted for SR101 (laser at $880 \mathrm{~nm}$ and emission filter $610 \pm 37 \mathrm{~nm}$, parameters that give faint images of few cells loaded with fura 2 only); same field as in (A). (B4) Of these 46 SR101 loaded astrocytes half ( $n=22$ ) were also fura 2-loaded (black-filled red circles obtained by superimposition of 1 and 3) meaning that 22 cells out of the 196 fura 2-loaded cells were astrocytes. Scale bars $50 \mu \mathrm{m}$.

$30 \mathrm{~min}$ in $1 \% \mathrm{H}_{2} \mathrm{O}_{2}$ in $\mathrm{PB}$. Slices were washed with $\mathrm{PB}$ and KPBS and incubated for $12 \mathrm{~h}$ in ABC complex at a dilution of $1: 100$ in KPBS $+0.3 \%$ triton (Abcys). They were rinsed in KPBS and incubated for approximately $10 \mathrm{~min}$ in $3,3^{\prime}$ diaminobenzidine (DAB $0.7 \mathrm{mg} / \mathrm{ml})$ with peroxide $(0.2 \mathrm{mg} / \mathrm{ml}$; Sigma Fast), rinsed, mounted in Crystal/Mount (Electron Microscopy Sciences), coverslipped, and examined. Dendritic and axonal fields were reconstructed using the Neurolucida system (MicroBrightField Inc., Colchester, VT, USA).
To reveal the Nkx2.1-positive neurons we used the antibody TTF-1/111-121. Slices were cryoprotected in PB with 20\% sucrose, freeze-thawed in isopentane, and rinsed in $\mathrm{PB}$. Slices were then incubated in PBS Triton $0.3 \%$ normal goat serum (NGS, 2\%) for $1 \mathrm{~h}$ and then in Nkx2.1 antibody (1:2500; TTF-1/111-121; Biopat, Italy) for 4 days at RT. After thorough rinsing, slices were incubated for $90 \mathrm{~min}$ at RT in alexa-488 goat anti-mouse (1:300; Molecular Probes, Leiden, the Netherlands) in PBS and NGS 2\% overnight. After thorough rinsing, slices were mounted in fluoromount, coverslipped, and examined with a confocal microscope (Zeiss LSM 510). For double immunocytochemistry Neurobiotin-Nkx2.1, slices were treated as above for the revelation of $\mathrm{Nkx} 2.1$. Then after thorough rinsing, slices were again incubated in PBS and Cy3 streptavidin (1:300; Jackson, USA) to label the neurobiotin-loaded neuron(s) and then rinsed. After thorough rinsing, slices were mounted in fluoromount, coverslipped, and examined with a confocal microscope (Zeiss LSM 510).

To visualize cortico-striatal axons, we injected small amounts of DiI crystals diluted in ethanol in the neocortex of $400 \mu \mathrm{m}$ thick slices from E16 to P2 brains postfixed by immersion for 2-4 weeks in $4 \%$ paraformaldehyde. Slices were then incubated in the fixative solution at $32^{\circ} \mathrm{C}$ for $2-3$ weeks, coverslipped, and examined with a confocal microscope (Zeiss LSM 510).

\section{ANALYSIS OF IMAGING DATA}

We performed analysis of the calcium activity with custom-made software written in Matlab (MathWorks; Bonifazi et al., 2009). The contour of each loaded cell was semi-automatically detected and its fluorescence measured as a function of time. Active cells are neurons exhibiting any $\mathrm{Ca}^{2+}$ event of at least $5 \% \mathrm{DF} / \mathrm{F}$ deflection within the period of recording. $\mathrm{Ca}^{2+}$ spikes or $\mathrm{Ca}^{2+}$ plateaus cells were neurons exhibiting at least one $\mathrm{Ca}^{2+}$ spike or one $\mathrm{Ca}^{2+}$ plateau within the period of recording. $\mathrm{Ca}^{2+}$ plateaus were intrinsic correlated $\mathrm{Ca}^{2+}$ events of long duration (see Results). Giant depolarizing potentials (GDP) cells were cells generating synchronized synapse-driven $\mathrm{Ca}^{2+}$ spikes (GDPs). To compute the activity correlation of two cells, the onset of each event was represented by a Gaussian ( $s=1$ frame, to allow some jitter). The inner product of the resulting values was then calculated. The significance of each correlation value was estimated by direct comparison with a distribution computed from surrogate data sets, in which the events were randomly reshuffled in time.

To compare both network-wide and single-neuron activity between putative intrinsically driven activity at P2 (P2-P3 recordings) and synaptically driven activity at P6 (P5-P7 recordings), we used standard $k$-means clustering to determine how well event durations and frequencies distinguished P2 and P6 time-points. The $k$-means algorithm used minimization of city-block distance, with 30 replications from random starting positions, from which we retained the replicate with the minimum mean distance. We also sought evidence for differences in spontaneous neural ensembles in network-wide activity. Each recording's matrix of pair-wise correlations, computed by Gaussian convolution as above was partitioned into groups using a modified community detection algorithm, detailed in Humphries (2011), which finds the number and size of groups within the matrix that maximize benefit function $Q_{\text {data }}=($ similarity within groups $)-($ expected similarity within 
groups). The resulting partition thus corresponded to groups of neurons that were more similar in activity patterns than was expected given the total similarity of each neuron's activity to the whole data-set. We then ran a further stringent control for potentially spurious groupings, by first shuffling the inter-event intervals of each neuron in a recording, correlating the shuffled event onsets, and then running the algorithm on the shuffled data-set. This was repeated 100 times to get a distribution of $Q$ for control data. The 95th percentile of these values was taken as the 95\% confidence interval $Q_{\text {ctrl }}$. Any network with $Q_{\text {data }}>Q_{\text {ctrl }}$ thus contained significant ensemble structure, compared to that expected from just the firing statistics of the network.

\section{ANALYSIS OF ELECTROPHYSIOLOGICAL DATA}

We determined series resistance $\left(R_{\mathrm{S}}\right)$, membrane capacitance $\left(C_{\mathrm{m}}\right)$, and input resistance $\left(R_{\text {input }}\right)$ by on-line fitting analysis of the transient currents in response to a $5-\mathrm{mV}$ pulse at $-70 \mathrm{mV}$. Criteria for considering a recording included $R_{\text {input }}>100 \mathrm{M} \Omega$, $R_{\mathrm{s}}<25 \mathrm{M} \Omega$, with $R_{\mathrm{s}}<30 \%$ change. We analyzed spontaneous postsynaptic currents (sPSCs) in $180 \mathrm{~s}$ recordings at a given membrane potential with the Mini-Analysis program (version 5.1.4; Synaptosoft, Decatur, GA, USA). Events were characterized by the following parameters: rise time (10-90\%), amplitude, and decay time $(\tau)$. We discriminated mixed AMPA/KA events in the absence of specific receptor antagonists from the SD given by the fit of each event to determine whether one or two exponentials best fitted the decays (Epsztein et al., 2005). E16-P5 MSNs generating sEPSCs (61 out of 131) or sIPSCs (33 out of 79) with a frequency lower than $0.05 \mathrm{~Hz}$ were not included.

We filtered the single-channel currents at $1 \mathrm{kHz}\left(\mathrm{GABA}_{\mathrm{A}}\right.$ channels) or $3 \mathrm{kHz}$ (NMDA channels) and digitized them at $10 \mathrm{kHz}$. We discarded multilevel and short $(2 \mathrm{~ms})$ openings during the analysis. To obtain unitary current-voltage $(I-V)$ relationships, we measured the amplitude of unitary GABA and NMDA currents evoked by steps from -120 to $+40 \mathrm{mV}$. Histograms of cursormeasured amplitudes allowed determination of the mean unitary current amplitude at each voltage tested.

Measurements of $V_{\text {rest }}$ and $E_{\mathrm{GABA}(\mathrm{A})}$ : to determine the action of GABA in a given neuron (depolarizing or hyperpolarizing), one must measure the reversal potential of the $\mathrm{GABA}_{\mathrm{A}}$-mediated current $\left[E_{\mathrm{GABA}(\mathrm{A})}\right]$ and the resting membrane potential $\left(V_{\text {rest }}\right)$. However, conventional whole cell recordings introduce a number of errors in these measures in particular in developing neurons. We therefore estimated the value of $V_{\text {rest }}$ from cell-attached recordings of the single-channel NMDA current ( $i$ NMDA), which is known to reverse at a membrane potential $\left(V_{\mathrm{m}}\right)$ close to $0 \mathrm{mV}$. We plotted the relationship between $i$ NMDA and the extracellular potential applied to the patch of membrane $\left(V_{\mathrm{p}}\right)$ from experimental data (see Figure 9B). This curve $\left[i \mathrm{NMDA}=f\left(V_{\mathrm{p}}\right)\right]$ gives the value of $V_{\mathrm{p}}$ when $i \mathrm{NMDA}=0 \mathrm{pA}$. At this value of $V_{\mathrm{p}}$, singlechannel NMDA current is null because $V_{\mathrm{m}}=V_{\mathrm{p}}-V_{\text {rest }}=0 \mathrm{mV}$. This allows estimation of $V_{\text {rest }}\left(V_{\text {rest }}=V_{\mathrm{p}}\right)$. To estimate $\left[E_{\mathrm{GABA}(\mathrm{A})}\right]$, we plotted the relationship between the single-channel $\mathrm{GABA}_{\mathrm{A}}$ current $\left(i \mathrm{GABA}_{\mathrm{A}}\right)$ and $V_{\mathrm{p}}$. This curve $\left[i \mathrm{GABA}_{\mathrm{A}}=\right.$ $f\left(V_{\mathrm{p}}\right)$ ] gives the value of $V_{\mathrm{p}}$ when $i \mathrm{GABA}_{\mathrm{A}}=0 \mathrm{pA}$ (see Figure 9A), because by definition when $i \mathrm{GABA}_{\mathrm{A}}$ is null, $V_{\mathrm{m}}=E_{\mathrm{GABA}(\mathrm{A})}$. Therefore, when $i \mathrm{GABA}_{\mathrm{A}}=0 \mathrm{pA}, V_{\mathrm{m}}=V_{\mathrm{p}}-V_{\text {rest }}=E_{\mathrm{GABA}(\mathrm{A})}$ (i.e., $\left.E_{\mathrm{GABA}(\mathrm{A})}-V_{\text {rest }}=-V_{\mathrm{p}}\right)$. By definition, $E_{\mathrm{GABA}(\mathrm{A})}-V_{\text {rest }}=$ $\mathrm{DF}_{\mathrm{GABA}}$, the driving force (DF) of chloride ions through the $\mathrm{GABA}_{A}$ channel (Tyzio et al., 2003). Therefore, when $i \mathrm{GABA}_{\mathrm{A}}=0 \mathrm{pA}, \mathrm{DF}_{\mathrm{GABA}}=-V_{\mathrm{p}}$. Knowing $V_{\text {rest }}$ and $\mathrm{DF}_{\mathrm{GABA}}$, it is easy to calculate $E_{\mathrm{GABA}(\mathrm{A})}=\mathrm{DF}_{\mathrm{GABA}}+V_{\text {rest }}$.

To obtain whole cell current-voltage $(I-V)$ relationships, we measured voltages at the end of each hyperpolarizing current step $(950 \mathrm{~ms})$. The inward rectification was detected when the $I-V$ relationship was not linear between -90 and $-120 \mathrm{mV}$. To compare immature and adult MSNs delay of firing in response to depolarizing steps, we measured the first interspike interval (ISI) of the response. We then pooled the slope values of the linear regression lines and compared their distribution as a function of time (Belleau and Warren, 2000). We estimated the threshold potential for $\mathrm{Na}^{+}$spikes in whole cell current clamp recordings at $V_{\text {rest }}(-70 \mathrm{mV}$ for E16-P7 slices and $-80 \mathrm{mV}$ for the adult slices) by applying successive intracellular depolarizing steps (duration $950 \mathrm{~ms}$ ) or in response to cortical stimulation.

\section{DRUGS}

Drugs were prepared as concentrated stock solutions and diluted in ACSF for bath application: bicuculline $20 \mu \mathrm{M}$, Gabazine $5 \mu \mathrm{M}, \mathrm{GABA}_{\mathrm{A}}$ receptor antagonists; (2R)-amino-5phosphonovaleric acid (APV) $40 \mu \mathrm{M}$, a NMDA receptor antagonist and $\left(2 S^{*}, 3 R^{*}\right)$-1-(Phenanthren-2-carbonyl)piperazine-2, 3-dicarboxylic acid (PPDA) $100 \mathrm{nM}$, a NR2C/D subunits antagonist; 6-cyano-7-nitroquinoxaline 2,3-dione (CNQX) $10 \mu \mathrm{M}$, and (2,3-dihydroxy-6-nitro-7-sulfamoyl-benzo[f] quinoxaline-2, 3-dione)(NBQX) 1-10 $\mu \mathrm{M}$, AMPA/kainate receptor antagonists. Nifedipine, an L-type $\mathrm{Ca}^{2+}$ channel antagonist; $\Omega$-Conotoxin GVIA, an $\mathrm{N}$-type $\mathrm{Ca}^{2+}$ channel antagonist; $\Omega$-Agatoxin IVA a $\mathrm{P} / \mathrm{Q}$ type $\mathrm{Ca}^{2+}$ channel antagonist; Isoguvacine $100 \mu \mathrm{M}$, a $\mathrm{GABA}_{\mathrm{A}}$ receptor agonist, was locally pressure-applied. All drugs were purchased from Sigma (St. Louis, MO, USA) except PPDA from Tocris and $\mathrm{N}$ or $\mathrm{P} / \mathrm{Q}$ type antagonists from Alomone Labs.

\section{MOTOR BEHAVIOR}

Motion development was assessed in Swiss newborn mice $(n=16)$ from two different litters (Janvier SAS, Le Genest Saint Isle, France) between postnatal day 2 (P2, day of birth: P0) and P12. C57BL/6 pups could not be tested because of their low weight. We used an open field test to assess overall activity. We tested each pup twice a day, with a 20-min delay between the two tests. We placed the pup on a translucid acrylic plate $(24 \mathrm{~cm} \times 16 \mathrm{~cm})$ covered with a silicone gel. Two cameras were placed below the plate. One acquired the pup's contact points with the floor which appeared as highly contrasted areas, based on the frustrated total internal reflection (FTIR) principle (Han, 2005). We identified the mouse abdominal contact points using custom-made software. The second camera acquired the trajectory of the pup. We calculated from this trajectory the total distance traveled, and the total distance traveled along straight line segments.

\section{STATISTICS}

Average values are presented as means \pm SEM and we performed statistical comparisons with Student's $t$-test (SigmaStat 3.1, Origin 5.0), Mann-Whitney rank sum test (SigmaStat 3.1) or one way 
ANOVA (Tukey's Test as post hoc test; SigmaStat 3.1, Origin 5.0). The appropriate descriptive statistic was chosen on this basis, as denoted in the text. We set the level of significance as $p \leq 0.05$. We grouped sets of data without statistical differences as follow: P2 (P0-P2), P6 (P3-P6), P8 (P7-P8), P10 (P9-P10), and P12 (P11-P12) except for Figures 2, 6, and 8 where the ages indicated correspond to the exact age $(-5=\mathrm{E} 14 ;-3=\mathrm{E} 16 ;-1=\mathrm{E} 18$; $0=\mathrm{P} 0 ; 2-30=\mathrm{P} 2-\mathrm{P} 30)$.

\section{RESULTS}

Fura 2-loaded striatal neurons were already active at E14, the youngest age tested. The percent of active cells was $16.8 \pm 1.5 \%$ between E14 and P0, and did not change significantly over the first postnatal week (P0-P2: $17.5 \pm 1.0 \%$ of imaged cells, P3$\mathrm{P} 6: 14.4 \pm 1.1 \% ; p=0.07)$. There were significantly fewer active cells at P7-P8 $(8.3 \pm 1.2 \%)$ and P9-P10 (4.2 $\pm 0.8 \% ; p=0.0004$ between the two groups P3-P6 and P7-P8, one way ANOVA, $n=\mathrm{a}$ total of 177 movies covering 47062 neurons). We then focused specifically on the activity of striatal MSNs. They generated three distinct patterns of activity: Intrinsic voltage-gated $\mathrm{Ca}^{2+}$ spikes (E14-P10), correlated $\mathrm{Ca}^{2+}$ Plateaus (E14-P10) and correlated $\mathrm{Ca}^{2+}$ spikes associated with (GDPs, P5-P7; Crepel et al., 2007; Allene et al., 2008). Of these three, only the latter was sensitive to blockers of glutamate and GABA synaptic transmission.

\section{EMBRYONIC AND EARLY POSTNATAL MSNS SPONTANEOUSLY GENERATE INTRINSICALLY DRIVEN CA ${ }^{2+}$ EVENTS IN THE ABSENCE OF SUBTHRESHOLD $\mathrm{K}^{+}$CURRENTS}

Intrinsic voltage-gated $\mathrm{Ca}^{2+}$ spikes predominated between E14 $(11.5 \pm 4.3 \%$ of imaged cells, $n=2268$ neurons in four fields, referred to as 2268/4), and P6 (10.2 $\pm 2.1 \%, 3143 / 12)$, and were significantly decreased at P10 $(3.1 \pm 0.9 \%, 2357 / 15 ; p=0.0008$, one way ANOVA; Figure 2A left, Figure $2 \mathrm{C}$ ). $\mathrm{Ca}^{2+}$ spikes were not necessarily associated with $\mathrm{Na}^{+}$spikes (Figure 2B left), had a low frequency $(0.028 \pm 0.004 \mathrm{~Hz}, 777 / 18)$, and a longer time to peak at E14-E18 $(1.31 \pm 0.08 \mathrm{~s}, 777 / 18)$ than at P0-P5 $(0.053 \pm 0.006 \mathrm{~Hz}$; $0.92 \pm 0.07 \mathrm{~s}, 207 / 7 ; p=0.004$ and $p=0.001$ respectively, Student's $t$-test) suggesting different $\mathrm{Ca}^{2+}$ channels and/or $\mathrm{Ca}^{2+}$ clearance properties. There were no cell pairs showing correlated $\mathrm{Ca}^{2+}$ spikes at any age $(0.2 \%$ at $\mathrm{E} 14,0.6 \%$ at $\mathrm{P} 6$, and $0 \%$ at P10).

Synchronized $\mathrm{Ca}^{2+}$ Plateaus were rare at E14 $(1.5 \pm 0.4 \%$ of imaged cells, 2268/4), peaked at P4 $(6.7 \pm 1.5 \%, 1166 / 5)$, and absent at P11-P12 (0\%, 1350/11; Figure 2A right, C). $\mathrm{Ca}^{2+}$ Plateaus were long lasting $\mathrm{Ca}^{2+}$ events $(6.45 \pm 2.01 \mathrm{~s}$, 234/22, at E14-E18) that significantly differed from $\mathrm{Ca}^{2+}$ spikes $(1.31 \pm 0.08 \mathrm{~s}, 777 / 19$, atE14-E18) in terms of duration $\left(p=2.2 \times 10^{-7}\right.$, Student's $t$-test). The percentage of cell pairs with correlated $\mathrm{Ca}^{2+}$ plateaus was around 5\% (6\% at E14, 5\% at P4). $\mathrm{Ca}^{2+}$ plateaus had a similar mean frequency at E18 and P4 $(0.014 \pm 0.003$ vs. $0.017 \pm 0.002 \mathrm{~Hz} ; p=0.8$, Student's $t$-test $)$ and a similar mean duration $(14.4 \pm 1.9$ vs. $14.5 \pm 0.8 \mathrm{~s} ; p=0.1$, Student's $t$-test; 107/10 and 89/5). Patch clamp recordings revealed underlying recurrent depolarizations $(22 \pm 2 \mathrm{mV}, 2.3 \pm 0.6 \mathrm{~s}$, at a frequency around $0.4 \mathrm{~Hz}, n=9$ ) or a single long lasting depolarization $(23 \pm 6 \mathrm{mV}, 10.0 \pm 3.7 \mathrm{~s}, n=4)$ that generated $\mathrm{Na}^{+}$spikes (Figure 2B right).

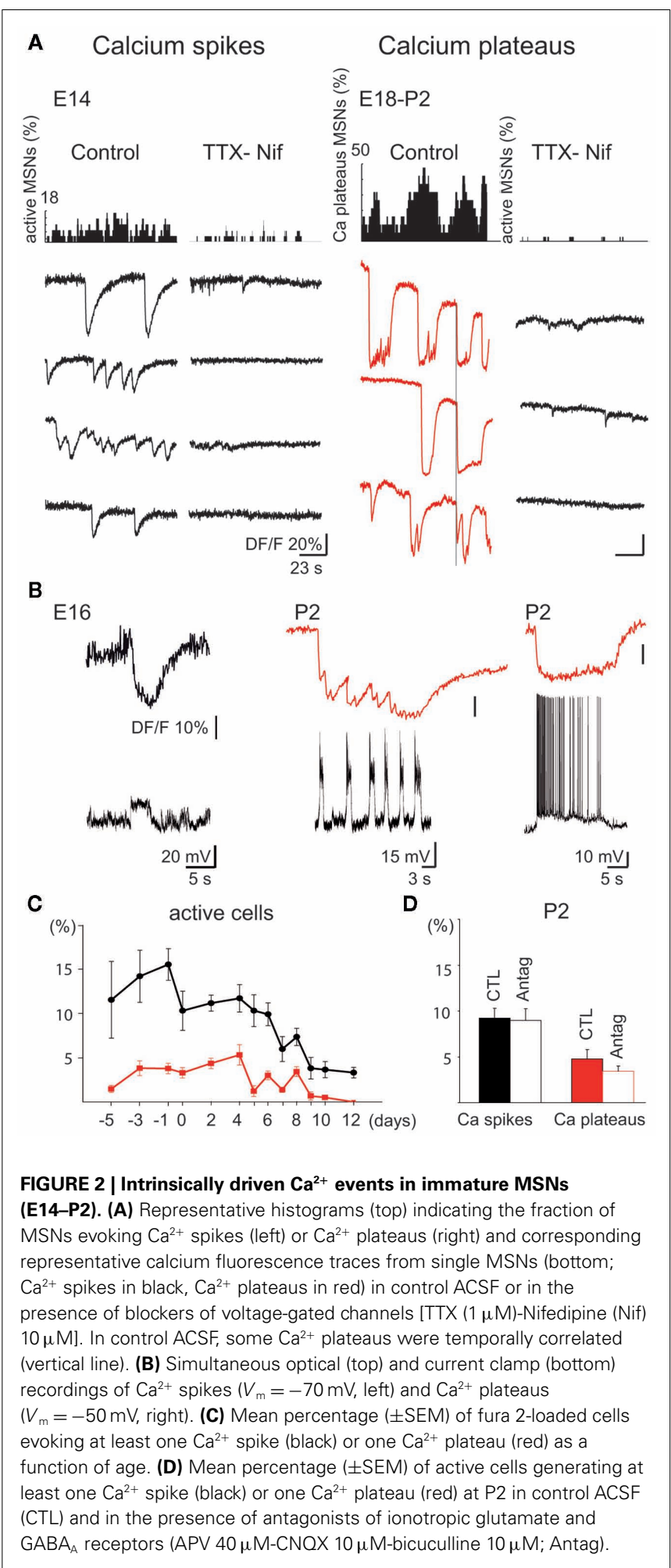

The blockers of $\mathrm{Na}^{+}$and $\mathrm{Ca}^{2+}$ voltage-gated channels, TTX $(1 \mu \mathrm{M})$-nifedipine $(10 \mu \mathrm{M})$ decreased threefold the percent of active cells (from $12.4 \pm 2.9$ to $4.6 \pm 2.2 \%$ of imaged cells at P2 (Figure 2A). Nifedipine alone at a concentration specific for Ltype $\mathrm{Ca}^{2+}$ channels $(3 \mu \mathrm{M})$ decreased the percent of active cells 
by $40 \%$ (from $13.9 \pm 3.6$ to $8.4 \pm 3.1 \%$; $p=0.04$, paired Student's $t$-test, 897/4) and $\omega$-Conotoxin GVIA $(1 \mu \mathrm{M})$, the N-type $\mathrm{Ca}^{2+}$ channel blocker, halved the percent of active cells (from $13.5 \pm 1.4 \%, 9682 / 33$ to $6.4 \pm 0.8 \%, 1321 / 6 ; p=0.0001$, Student's $t$-test; not shown). In contrast, $\Omega$-Agatoxin IVA $(100 \mathrm{nM})$, the specific blocker of $\mathrm{P} / \mathrm{Q}$ type channels had no significant effect. Ionotropic glutamate and GABA antagonists did not affect the percentage of $\mathrm{Ca}^{2+}$ spike cells (9.2 \pm 1.1 vs. $9.0 \pm 1.3 \%$ at $\mathrm{P} 2, p=0.79$, paired Student's $t$-test) or $\mathrm{Ca}^{2+}$ plateaus cells (Figure $2 \mathrm{D}$ ). These antagonists also did not significantly affect the coherence between calcium plateaus $(4.5 \%$ pairs of plateaus cells correlated in the presence of antagonists vs. 5\% pairs in control at P2).

The time coherence between some $\mathrm{Ca}^{2+}$ plateaus could be explained by the presence of gap junctions between immature neurons (Crepel et al., 2007). Single MSN recordings with neurobiotin-containing pipettes revealed clusters of $6 \pm 1$ neurobiotin-labeled neurons at E14-E18 ( $n=13 / 17$ patches), but of only two MSNs at P30-P40 ( $n=3 / 38$ patches). The majority of clusters were exclusively composed of MSNs (E14-P2, $n=36 / 37$ clusters) and were abundant until P0-P2 (Figure 3). This suggested the presence of gap junctions permeable to neurobiotin at perinatal stages as described in juvenile rodent MSNs (Tepper et al., 1998; Venance et al., 2004) and required for the formation of synaptically connected networks (Todd et al., 2010). But carbenoxolone $(100 \mu \mathrm{M})$, like mefloquine $(25 \mu \mathrm{M})$ applied during 10-20 min, similarly reduced the probability of occurrence of all types of immature $\mathrm{Ca}^{2+}$ activities (data not shown, E14-P4, $5653 / 17)$. This non-specific effect precluded their use for demonstrating the role of gap junctions in $\mathrm{Ca}^{2+}$ plateaus' occurrence. These results suggested that $\mathrm{Ca}^{2+}$ spikes and $\mathrm{Ca}^{2+}$ plateaus are non-synaptic, intrinsic, voltage-gated events generated by $\mathrm{Na}^{+}$ and $\mathrm{L}$ and $\mathrm{N}$-types $\mathrm{Ca}^{2+}$ channels. To understand how MSNs spontaneously generate intrinsically driven calcium events, we next investigated the development of their intrinsic membrane properties.

The membrane potential trajectory attributable to the activation of the inwardly rectifying $\mathrm{K}^{+}$current $\left(I \mathrm{~K}_{\mathrm{IR}}\right)$ was not detected in any MSNs at E14, was present in $17 \%$ of MSNs at P7 $(n=3 / 44)$ and in all MSNs at P10 and P30 ( $n=8 / 8$ and 6/6, respectively). It greatly increased from P10 to P30 (Figures 4A,B). Accordingly, bath application of cesium $(3 \mathrm{mM})$, a blocker of $I \mathrm{~K}_{\mathrm{IR}}$, increased the proportion of active cells by $240 \%$ at P6-P10 (from $4.3 \pm 1.1$ to $10.4 \pm 1.7 \%, 1349 / 6 ; p=0.04$ paired Student's $t$-test; data not shown). The mean input resistance $\left(R_{\mathrm{m}}\right)$ of MSNs was high until P6 and significantly decreased by approximately $75 \%$ between $\mathrm{P} 6$ and $\mathrm{P} 10$ (from $982 \pm 129 \mathrm{M} \Omega$ at P6, $n=21$ to $263 \pm 19 \mathrm{M} \Omega$ at P10, $n=11 ; p=0.004$, one way ANOVA; Figure 4C). Spiking threshold ( $V_{\text {threshold }}$ ) did not change from P2 to P30 (P2: $-32.2 \pm 1.7 \mathrm{mV}, n=14$ and $\mathrm{P} 30:-30.8 \pm 0.8 \mathrm{mV}, n=10 ; p=0.51$ one way ANOVA) but the instantaneous firing frequency did. The first ISI of a firing train as a function of injected current was stable until P6 and was then significantly reduced between P6 and P10 $(1.44 \pm 0.14 \mathrm{~Hz} / \mathrm{pA}, n=11$ at $\mathrm{P} 6$ vs. $0.91 \pm 0.08 \mathrm{~Hz} / \mathrm{pA}$, $n=7$ at $\mathrm{P} 10 ; p=0.03$, one way ANOVA) showing an increased delay to spiking at P10 (Figures 4D,E). The depolarization needed to generate spikes calculated as $\left(V_{\text {threshold }}-V_{\text {rest }}\right)$ from whole cell recordings (Figures 4F,G) was significantly lower until P6

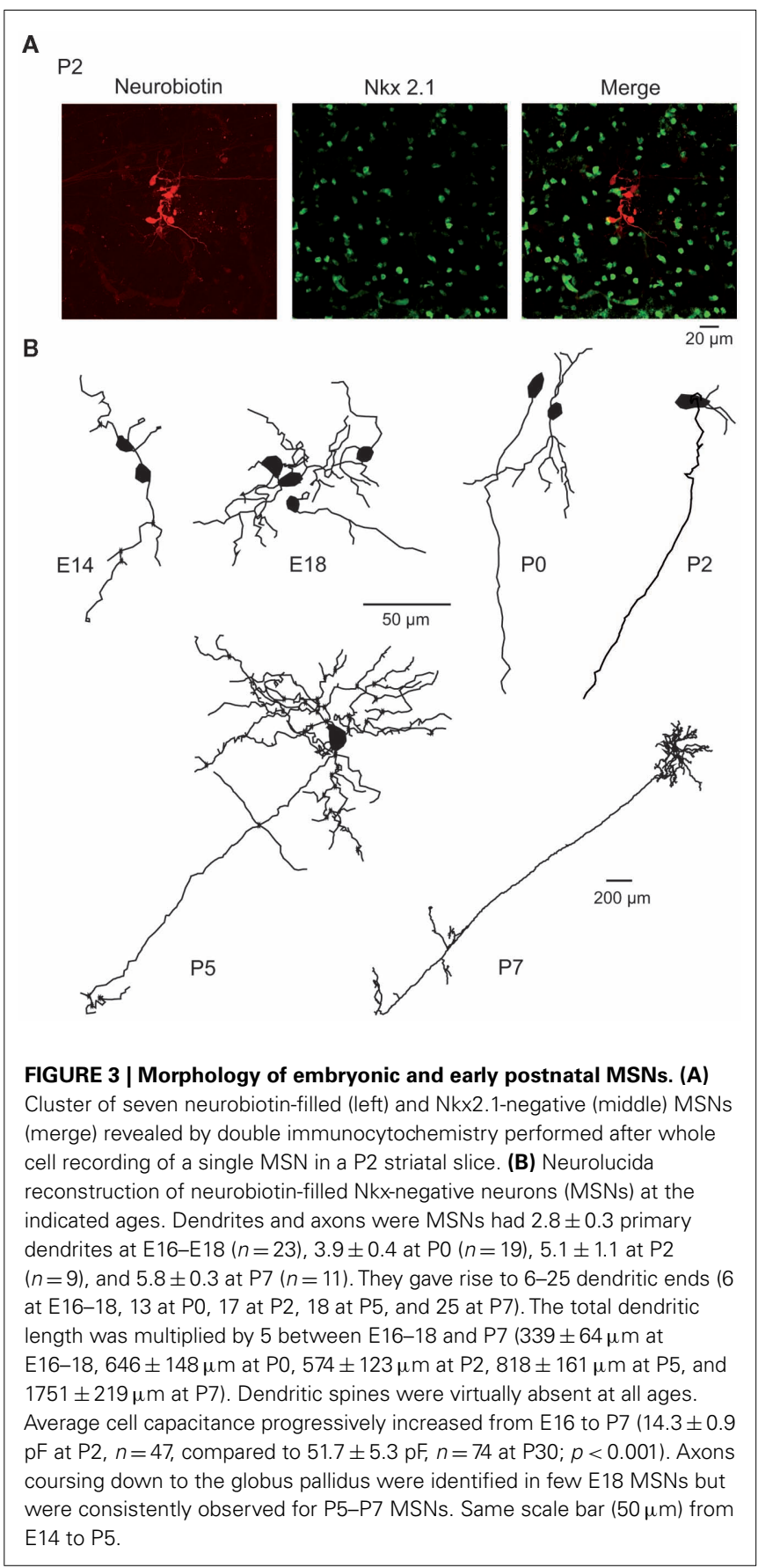

than after $(23 \pm 3 \mathrm{mV}$ at $\mathrm{P} 6, n=15$ and $37 \pm 2 \mathrm{mV}$ at $\mathrm{P} 10, n=6$; $p=0.023$, one way ANOVA). $V_{\text {rest }}$ measured from unitary NMDA currents was also significantly hyperpolarized between P2 and P10. Using single-channel recordings of NMDARs to provide an accurate measure of $V_{\text {rest }}$ in young neurons (Tyzio et al., 2003; see Results of Figure 9), we found a significant decrease in $V_{\text {rest }}$ between $\mathrm{P} 2$ and $\mathrm{P} 10(-70.0 \pm 1.7 \mathrm{mV}$ at $\mathrm{P} 2,-77.0 \pm 1.3 \mathrm{mV}$ at P10; $n=11$ and 11, respectively; $p=0.009$, one way ANOVA test; see Dehorter et al., 2009 for extensive discussion of the method; Figure 4G). These results suggest that until P6, MSNs lack $\mathrm{K}^{+}$currents like $\mathrm{K}_{\mathrm{iR}}, \mathrm{K}_{\mathrm{D}}$, and probably leak $\mathrm{K}^{+}$currents as well, including 


\section{A Inward rectification}
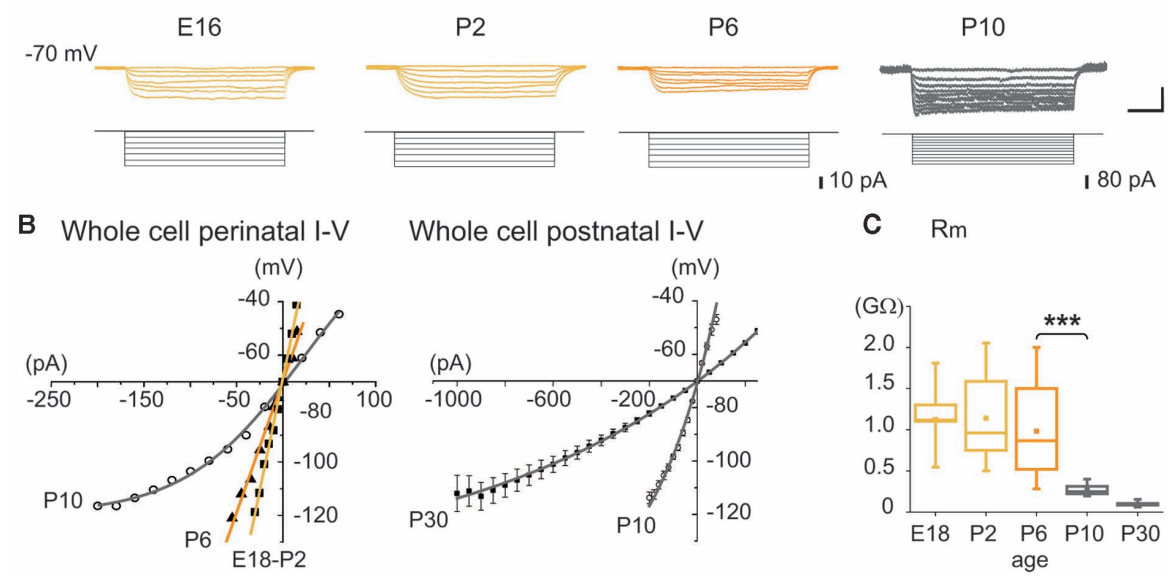

C $\mathrm{Rm}$

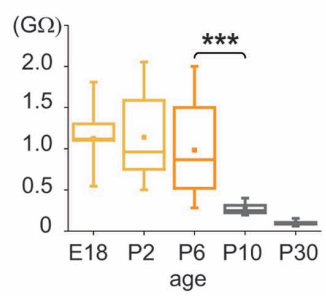

D Spike threshold and delay

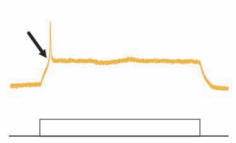

E First ISI

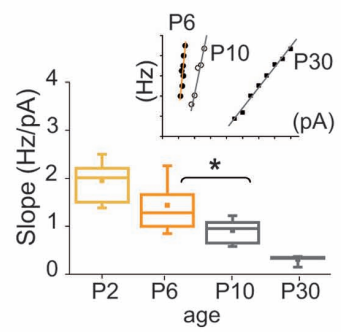

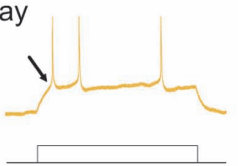

F Vthreshold

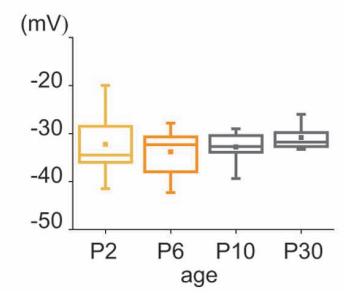

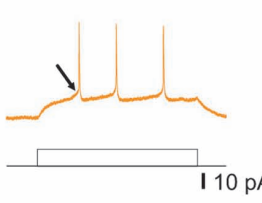

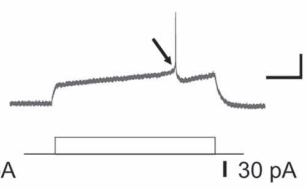

G Vrest, single channel

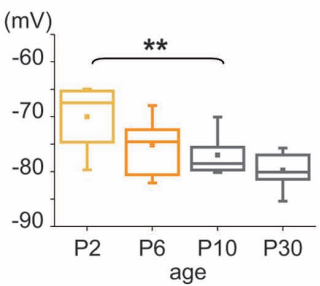

FIGURE 4 | Intrinsic membrane properties of MSNs as a function of age. (A) Representative whole cell current clamp responses of embryonic and postnatal MSNs to intracellular hyperpolarizing steps $\left(V_{\mathrm{m}}=-70 \mathrm{mV}\right)$. Note the absence of inward rectification before P10. Scale bars: $25 \mathrm{mV}$; $200 \mathrm{~ms}$. (B) Whole cell $I-V$ relationships at the indicated ages, obtained from experiments in (A). (C) Input membrane resistance $\left(R_{\mathrm{m}}\right)$ as a function of age obtained from experiments in a. (D) Representative whole cell current clamp responses to intracellular depolarizing steps $\left(V_{m}=-70 \mathrm{mV}\right)$. At E16-E18 few MSNs generated suprathreshold $\mathrm{Na}^{+}$spikes (14\%, $\left.n=1 / 8\right)$,
$50 \%$ at $\mathrm{P} 0(n=3 / 6), 64 \%$ at $\mathrm{P} 2(n=16 / 25), 87 \%$ at $\mathrm{P} 5(n=21 / 24)$, and $100 \%$ at P7 ( $n=12 / 12)$. Scale bars: $25 \mathrm{mV} ; 200 \mathrm{~ms}$. (E) Instantaneous firing frequency to the first interspike interval (ISI) of a firing train as a function of injected current (insert, scale: $20 \mathrm{~Hz}, 100$ pA). Slope values given by each linear regression lines fitted to frequency curves (correlation coefficient were all $>0.9$ ) as a function of postnatal age. (F) Threshold potential $\left(V_{\text {threshold }}\right)$ as a function of age calculated from experiments in d. (G) Resting membrane potential $\left(V_{\text {rest }}\right)$ determined from the reversal potential of unitary NMDA currents in MSNs. members of the KCNK class expressed in adult MSNs (Shen et al., 2007). Consequently, $R_{\mathrm{m}}$ is high (900 M $\Omega$ ), $V_{\text {rest }}$ is only $20 \mathrm{mV}$ more hyperpolarized than $V_{\text {threshold }}$ and there is no spiking delay. Because of this, spontaneous $\mathrm{Ca}^{2+}$ channel openings may occur and give rise to spontaneous $\mathrm{Ca}^{2+}$ events.

\section{EARLY POSTNATAL MSNS GENERATE CORRELATED $\mathrm{Ca}^{2+}$ SPIKES WHEN THEY EXPRESS THE NR2C/D NMDA SYNAPTIC CURRENT AND MEMBRANE PROPERTIES ARE STILL IMMATURE}

The first synapse-driven pattern observed in postnatal MSNs was correlated $\mathrm{Ca}^{2+}$ spikes (GDPs), that appeared at P5-P7 (10\% of the recordings, 969/5; mean frequency: $0.10 \pm 0.05 \mathrm{~Hz}$ and mean duration: $0.70 \pm 0.10 \mathrm{~s}, 102 / 5)$, and subsequently disappeared. The vast majority of active striatal neurons $(84.0 \pm 9.7 \%)$ were engaged in this activity with a large number of correlated cell pairs $(24 \%)$, attesting to the large neuronal ensemble that fired together during these events (Figure 5A left). Electrophysiological activity underlying each GDP consisted of bursts of $2-3 \mathrm{Na}^{+}$spikes (Figure 5B). Ionotropic glutamate and GABA receptor antagonists abolished GDPs, but left other $\mathrm{Ca}^{2+}$ events (uncorrelated $\mathrm{Ca}^{2+}$ spikes or $\mathrm{Ca}^{2+}$ plateaus) intact ( $p=0.02$ and 0.52 respectively, paired Student's $t$-test; Figures 5A-D). Since GDPs were also suppressed by APV $(40 \mu \mathrm{M})$ alone, suggesting that NMDA receptors were heavily involved, we tested their sensitivity to PPDA (Feng et al., 2004), the preferential antagonist of NR2C/D NMDA receptors. At $100 \mathrm{nM}$ PPDA removed most of the correlations between neurons (from 45 to $11 \%$ ). Most of the GDP cells stopped their activity and the few who did not, evoked $\mathrm{Ca}^{2+}$ spikes at a much lower frequency (from $0.17 \pm 0.01$ to $0.07 \pm 0.01 \mathrm{~Hz} ; p=0.0003$, Mann-Whitney test; Figures 5C,D). 


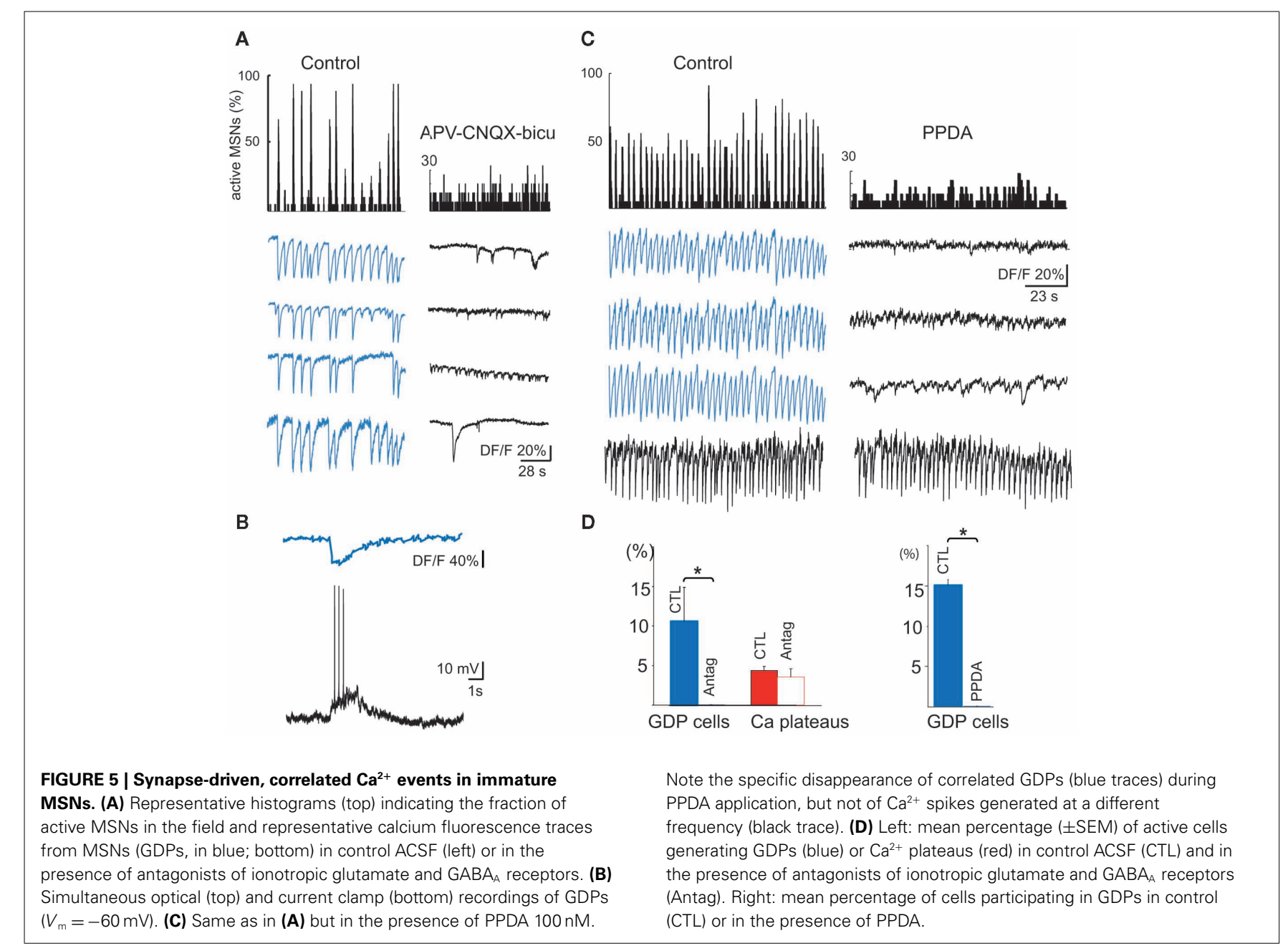

To understand the time course of development of the spontaneous synaptic activities afferent to MSNs and that could play a role in the transiently expressed GDPs, we performed separate recordings of glutamatergic and GABAergic synaptic events. Glutamatergic events: the fraction of MSNs exhibiting AMPA- or KA-mediated sEPSCs steadily increased from E16 to E18 (38 and $50 \%)$ to a maximum at P5-P7 (100\%). The mean frequency of AMPA or KA receptor-mediated EPSCs gradually increased from E16 to E18 $(0.11 \pm 0.04$ and $0.3 \pm 0.1 \mathrm{~Hz} ; n=5$ and $5 \mathrm{MSNs})$ to P30 $(1.3 \pm 0.7$ and $0.9 \pm 0.2 \mathrm{~Hz} ; n=5$ and $6 \mathrm{MSNs} ; p=0.03$ and $p=0.004$ respectively, one way ANOVA) but their amplitude ( $p=0.3$ for AMPA, $p=0.07$ for KA, one way ANOVA), rise times and decay times remained constant (Figures 6A-E left and middle). In contrast, the fraction of MSNs showing spontaneous NMDA receptor-mediated EPSCs shifted from $40 \%$ at P0 (5/12 cells) to more than $90 \%$ at $\mathrm{P} 5-7(16 / 18)$, and decreased thereafter to $30 \%$ at P30 (4/12; Figures 6 A,B right). Their frequency stayed constant and low (around $0.1 \mathrm{~Hz}, p=0.9$; one way ANOVA) and also their amplitude $(p=0.9)$ and rise times but their decay time significantly decreased in the same period (Figures 6C-E right).

Since the cortex provides a major source of glutamatergic inputs to MSNs, we studied the development of these inputs. DiI labeling of the neocortex $(n=5)$ revealed fiber staining in the striatum as early as E16 (Figure 7A). These inputs are functional, because cortical stimulation evoked glutamatergic EPSPs in $10 \%$ of MSNs at E16 $(n=2 / 18), 64 \%$ at $\mathrm{P} 0-\mathrm{P} 2(n=20 / 31), 75 \%$ at $\mathrm{P} 5-\mathrm{P} 7$ $(n=9 / 12), 80 \%$ at $\mathrm{P} 10(n=9 / 11)$, and $86 \%$ at $\mathrm{P} 30(n=12 / 14)$. This was associated with a dramatic decrease in EPSP duration between P6 and P30 $(-82 \%)$ and of the number of spikes they generated. At P2, EPSPs $(311 \pm 32 \mathrm{~ms} ; n=6)$ generated 1 spike or spikelet, at P6 $(420 \pm 41 \mathrm{~ms} ; n=8) 2-5$ spikes, while by P10 EPSPs had shortened to $276 \pm 36 \mathrm{~ms}$ ( $n=7 ; p=0.03$, between P6 and P10, one way ANOVA) and only gave rise to one spike as at P30 (74 $\pm 7 \mathrm{~ms}, n=7$; Figure 7B). At P6, the large EPSPs (and GDPs) were mostly blocked by the NMDA receptor antagonist APV, suggesting that NMDA receptors were heavily involved in early cortico-striatal activity. The long decay of P6 EPSPs suggested a preferential contribution of NR2C/D subunits of NMDA receptors with their long kinetics and reduced voltage-dependent magnesium block (Monyer et al., 1994). The NR2C/D subunit inhibitor PPDA (100 nM; Feng et al., 2004) significantly reduced evoked EPSPs at P6 $(-54 \% ; p=0.01, n=6$; paired Student's $t$ test) but not at P2 ( $-13 \% ; p=0.18, n=5$; paired Student's $t$-test $)$ or P10 ( $-9 \% ; p=0.15, n=5$; paired Student's $t$-test; Figure 7C), 


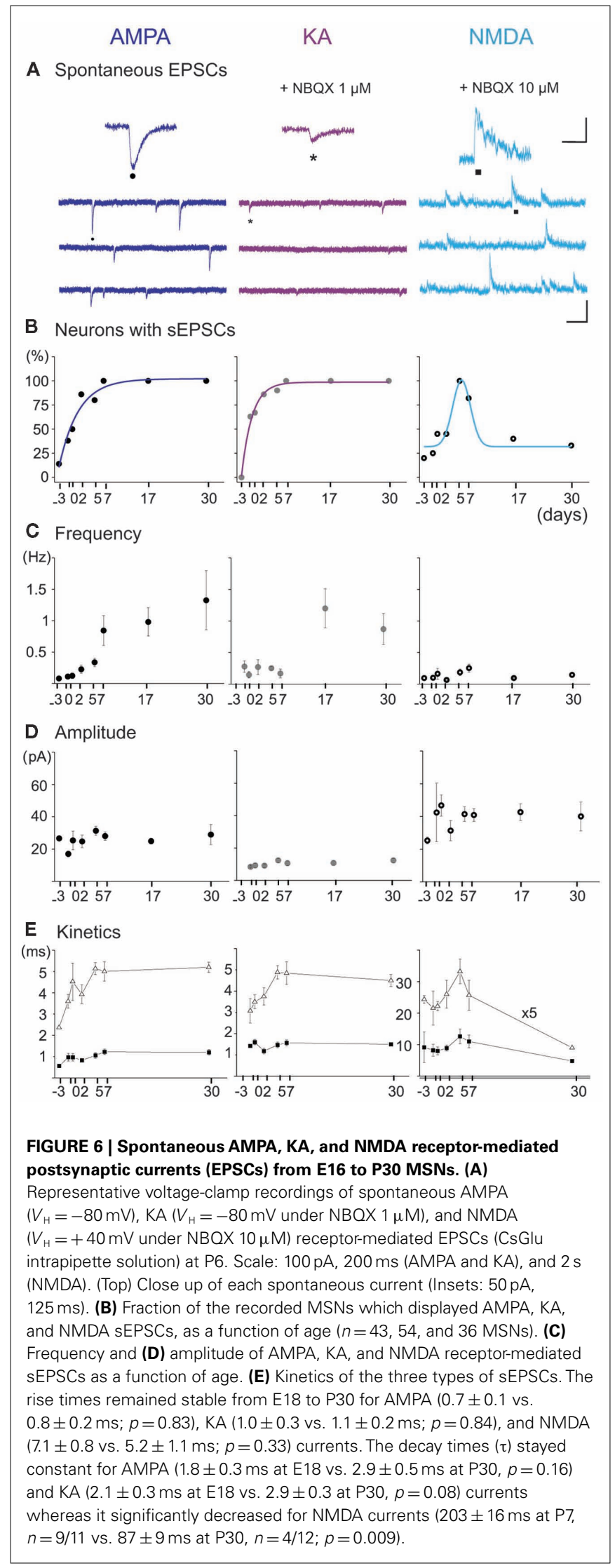

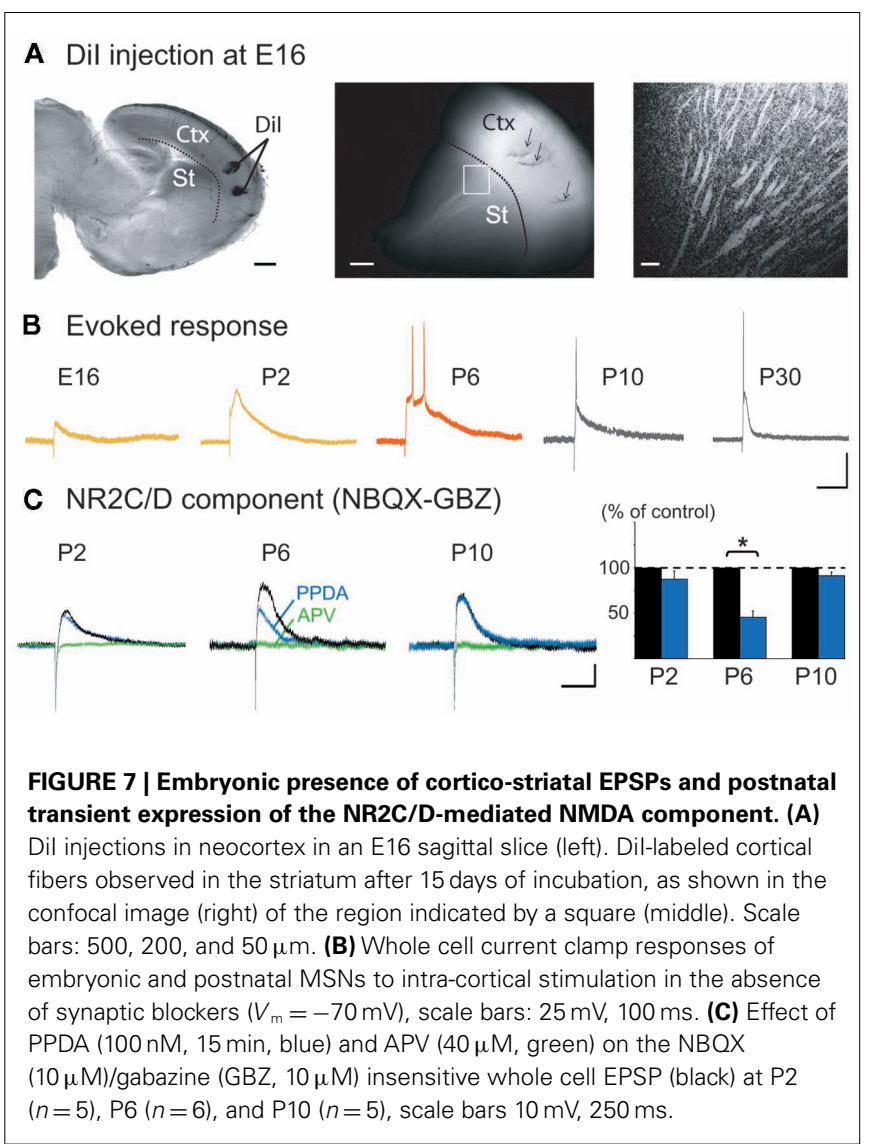

showing a restricted participation of NR2C/D before and after P6. The presence of a large NR2C/D-mediated NMDA component enables cortico-striatal synapses to generate large EPSCs associated with bursts of spikes at P5-P7, but not at P10.

\section{GABAergic events}

The fraction of MSNs exhibiting spontaneous $\mathrm{GABA}_{\mathrm{A}} \mathrm{R}$-mediated currents steadily increased from E16 to a maximum at P5-P7 and the mean frequency of these currents $\left(\mathrm{GABA}_{\mathrm{A}} \mathrm{PSCs}\right)$ progressively increased from E16 up to P30 (519 MSNs; Figures 8A-C). The DF of GABA $\left(\mathrm{DF}_{\mathrm{GABA}}\right)$, determined from single-channel recordings of $\mathrm{GABA}_{\mathrm{A}}$ Rs (see Materials and Methods; Tyzio et al., 2003), was similarly depolarizing by $15 \mathrm{mV}$ at $\mathrm{P} 2(+15.3 \pm 3.4 \mathrm{mV}$; $n=8$ MSNs, Figures 9A,B) and P30 (Dehorter et al., 2009; $+16.1 \pm 1.9 \mathrm{mV}, n=11 ; p=0.8$, Student's $t$-test). To estimate $\left(E_{\mathrm{GABA}_{\mathrm{A}}}\right)$, we plotted the relationship between the single-channel $\mathrm{GABA}_{\mathrm{A}}$ current $\left(i \mathrm{GABA}_{\mathrm{A}}\right)$ and the pipette potential $\left(V_{\mathrm{p}}\right)$. This curve $\left[i \mathrm{GABA}_{\mathrm{A}}=f\left(V_{\mathrm{p}}\right)\right]$ gives the value of $V_{\mathrm{p}}$ when $i \mathrm{GABA}_{\mathrm{A}}=0 \mathrm{pA}$ (Figures $\mathbf{9 A}, \mathbf{B}$ right), because when $i \mathrm{GABA}_{\mathrm{A}}$ is null, $V_{\mathrm{m}}=E_{\mathrm{GABA}_{\mathrm{A}}}$. Therefore, when $i \mathrm{GABA}_{\mathrm{A}}=0 \mathrm{pA}, V_{\mathrm{m}}=$ $V_{\mathrm{p}}-V_{\text {rest }}=E_{\mathrm{GABA}_{\mathrm{A}}}$ (i.e., $E_{\mathrm{GABA}_{\mathrm{A}}}-V_{\text {rest }}=-V_{\mathrm{p}}$ ). By definition, $E_{\mathrm{GABA}_{\mathrm{A}}}-V_{\text {rest }}=\mathrm{DF}_{\mathrm{GABA}_{\mathrm{A}}}$, the $\mathrm{DF}$ of chloride ions through the $\mathrm{GABA}_{\mathrm{A}}$ channel (Tyzio et al., 2003). Therefore, when $I_{\mathrm{GABA}_{\mathrm{A}}}=0 \mathrm{pA}, \mathrm{DF}_{\mathrm{GABA}_{\mathrm{A}}}=-V_{\mathrm{p}}$. Knowing $V_{\text {rest }}$ and $\mathrm{DF}_{\mathrm{GABA}_{\mathrm{A}}}$, we can calculate the reversal potential for $\mathrm{GABA}_{\mathrm{A}}, E_{\mathrm{GABA}_{\mathrm{A}}}=$ $\mathrm{DF}_{\mathrm{GABA}_{\mathrm{A}}}+V_{\text {rest }}$. The reversal potential of $\mathrm{GABA}_{\mathrm{A}}$ currents was 


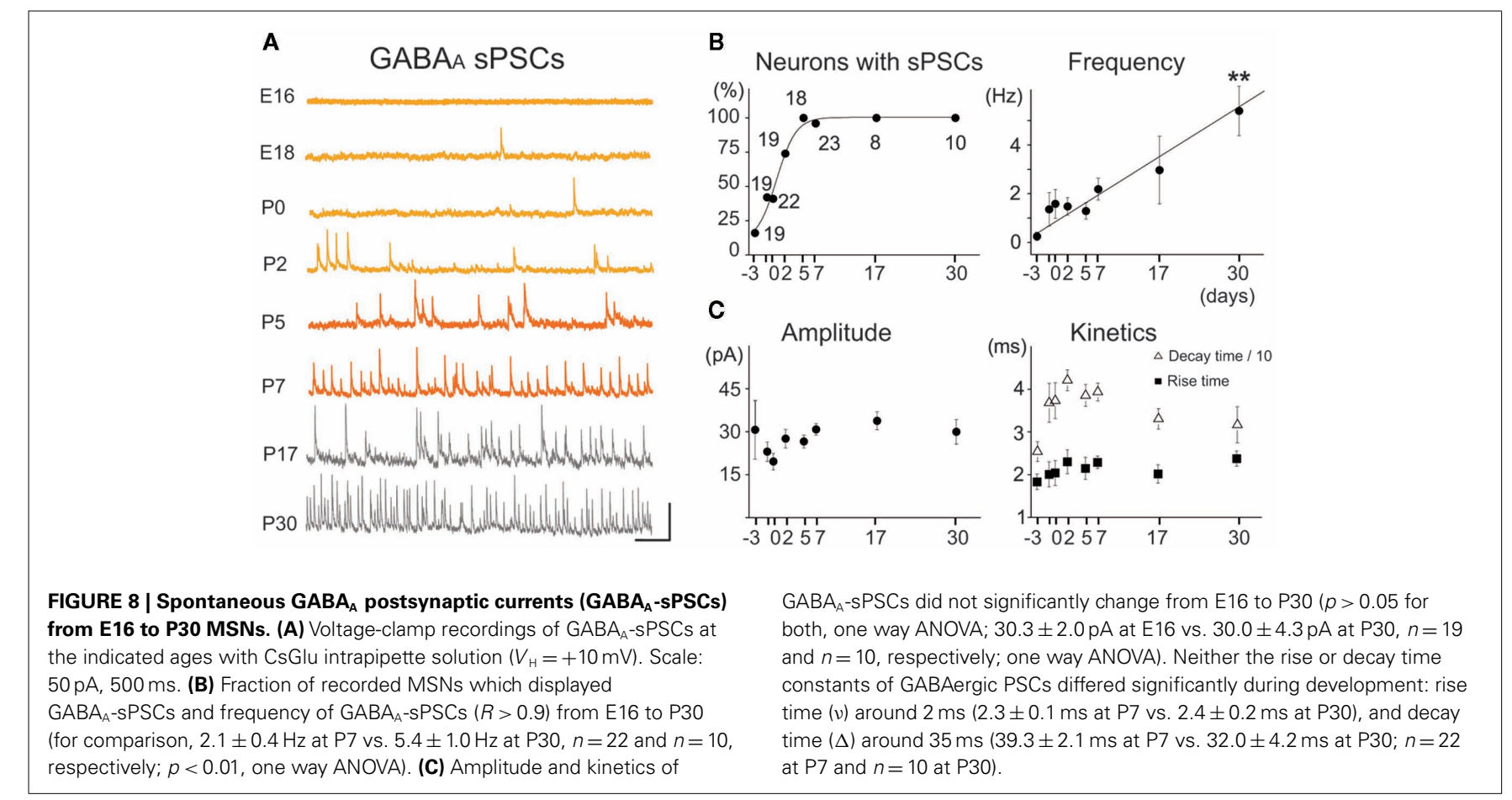

$10 \mathrm{mV}$ more depolarized at P2 than at P30 (Figure 9C). These values are based on the assumption that the NMDA current reverses at $0 \mathrm{mV}$ in MSNs. Although an error of $5 \mathrm{mV}$ may exist (Tyzio et al., 2003), the comparison of $V_{\text {rest }}$ and $E_{\mathrm{GABA}}$ obtained with the same methods at P2 and P30 confirms the validity of our conclusions. Therefore, GABAergic synapses depolarize MSNs from $V_{\text {rest }}$ to a value closer to the action potential threshold than in the adult (Misgeld et al., 1982; Koos and Tepper, 1999). However, GABA does not excite immature MSNs. Focal applications of the $\mathrm{GABA}_{\mathrm{A}}$ receptor agonist isoguvacine failed to generate action potentials in cell-attached recordings from P2 $(n=6$, Figure 9D) or P5 ( $n=7$, data not shown) MSNs. Similarly, stimulation of the striatal neuropil failed to evoke action potentials in cell-attached recordings of MSNs in the continuous presence of ionotropic glutamate receptors antagonists (data not shown).

The above data show that striatal neurons generate GDPs during a transient period when all MSNs are connected to glutamatergic and GABAergic neurons and still exhibit immature membrane properties (see Figure 4). There is a more efficient GABAergic depolarizing drive than at P30 that may participate in the GDPs of P5-P7 MSNs (together with glutamatergic EPSPs; Bracci and Panzeri, 2006) but these events are mainly driven by cortico-striatal synapses at a time where cortical neurons also generate GDPs (Allene et al., 2008).

\section{INTRINSIC AND SYNAPSE-DRIVEN IMMATURE ACTIVITY DERIVE FROM DISTINCT NEURAL ENSEMBLES}

Because approximately $90 \%$ of the P5-P7 striatal networks did not generate GDPs at the time of recording, we wanted to understand whether synapse formation in some way altered the dynamics of the network. We compared network-wide activity at P2-P3 (when synapse density is low) to that at P5-P7 (when all MSNs are innervated by glutamatergic and GABAergic inputs). We found that both frequency and duration of events changed from $\mathrm{P} 2-\mathrm{P} 3$ to P5-P7 (Figures 10A,B). The distributions of mean event frequency significantly differed between P2-P3 and P5-P7 (MannWhitney $U$-test; $n_{\mathrm{P} 2}=18, n_{\mathrm{P} 6}=33 ; U=320 ; p=0.02$ ). Similarly, the distributions of median event duration significantly differed between P2-P3 and P5-P7 ( $U=569.5, p=0.0046)$. To gage the size of these differences between P2-P3 and P5-P7, we used $k$ means clustering to assign each recording to either $\mathrm{P} 2-\mathrm{P} 3$ or $\mathrm{P} 5-\mathrm{P} 7$ on the basis of its event statistics. We found that both duration (70\% correct assignments) and frequency (64\% correct) reliably indicated a recording's developmental stage. Thus, the switch from intrinsically to synaptically driven activity reliably decreased duration and increased the frequency of calcium events in the immature striatal network.

Both P2-P3 and P5-P7 networks were capable of showing spontaneous formation of neural ensembles (Figures 10C,D). We found markedly more P5-P7 $(43 \%, 9 / 21)$ than P2-P3 (29\%, $4 / 18$ ) recordings with significant ensemble structure. Conversely, these P2-P3 recordings contained more ensembles (range 5-9) than the P5-P7 recordings (range 2-6). We also found that the P5-P7 recordings with GDP-driven, network-wide synchronization could be sub-divided into ensembles that indicated the delay in a neuron's participation of the network-wide synchronization (Figure 10E). These results suggest that the transition from intrinsic to synaptically driven activity promoted the appearance of putative cell assemblies.

\section{ABRUPT LOSS OF GDPS AND SWITCH TO ADULT-LIKE INTRINSIC PROPERTIES OCCURS BEFORE COORDINATED LOCOMOTION}

As shown in Figures 11A-E, many MSN characteristics changed abruptly between P6 and P10. MSNs become mostly silent 


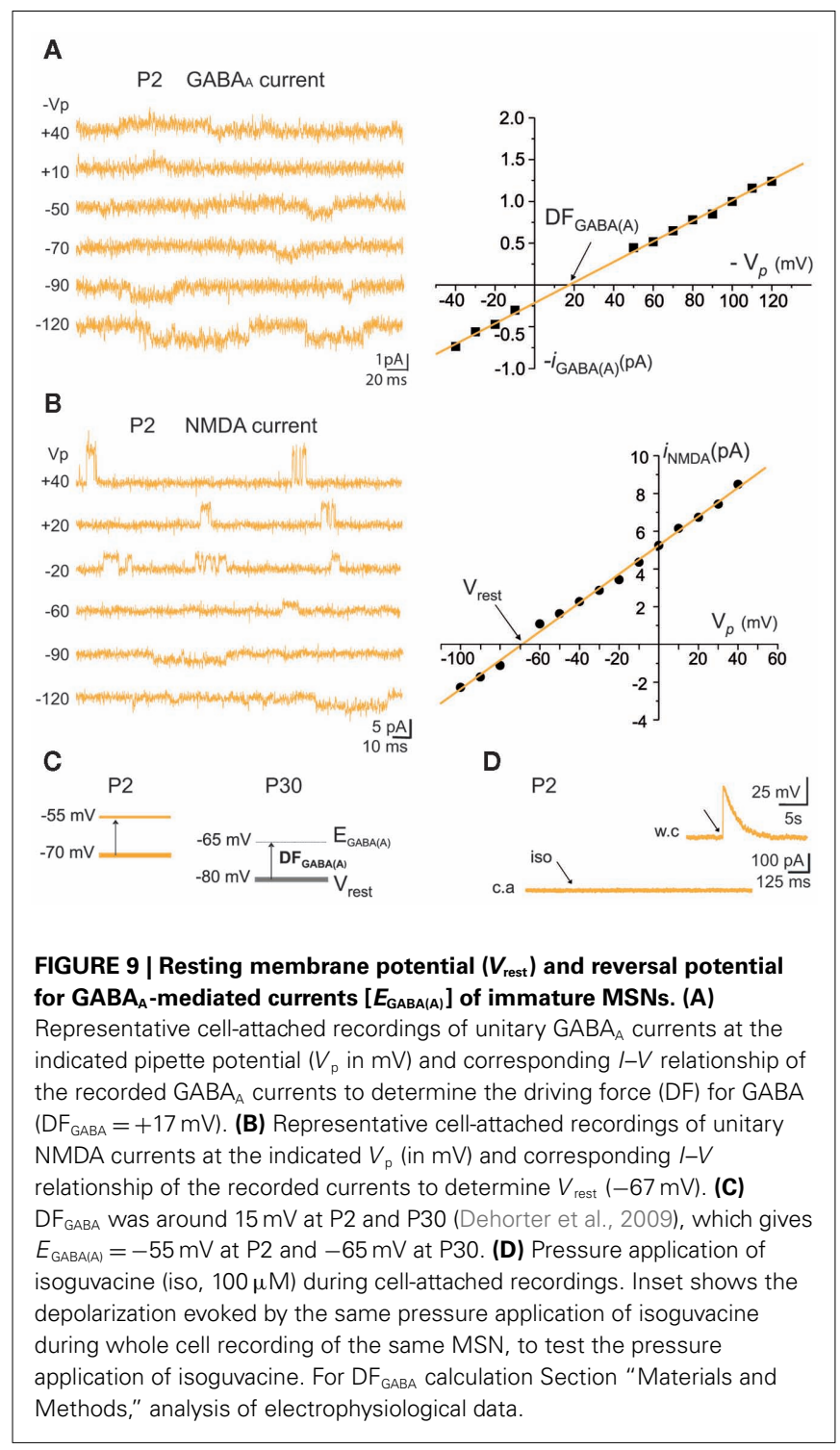

at P10, entering an adult-like phase. AMPA or KA receptormediated signals are probably not involved in the extinction of early spontaneous activity in MSNs because their frequency continuously increases with age. In contrast, the switch in other properties such as the abrupt loss of NR2C/D, expression of $I \mathrm{~K}_{\mathrm{IR}}$, decrease in $R_{m}$, hyperpolarization of $V_{\text {rest }}$, and hyperpolarization of $E_{\mathrm{GABA}_{\mathrm{A}}}$ all coincided with the silencing of MSNs.

In order to identify when the transition of MSNs from immature to adult-like state occurs in relation to a motor behavioral output, we quantified the maturation of pup body contacts and motion. At P2, prior to the onset of quadruped ambulation, the duration of abdominal contact with the cage surface was high $(35.3 \pm 4.9 \%$ of total time), then progressively decreased at P3-P6 (17.8 $\pm 1.6 \%)$ and P7-P8 (2.9 $\pm 0.7 \%)$, disappearing by P9-P10 $\left(n=16 ; p=1 \times 10^{-8}\right.$ between P3-P6 and P7-P8; one way ANOVA; Figures 11F,G, top). Body motion was practically absent at $\mathrm{P} 2$, with pivoting and crawling predominating in $\mathrm{P} 3-\mathrm{P} 7$
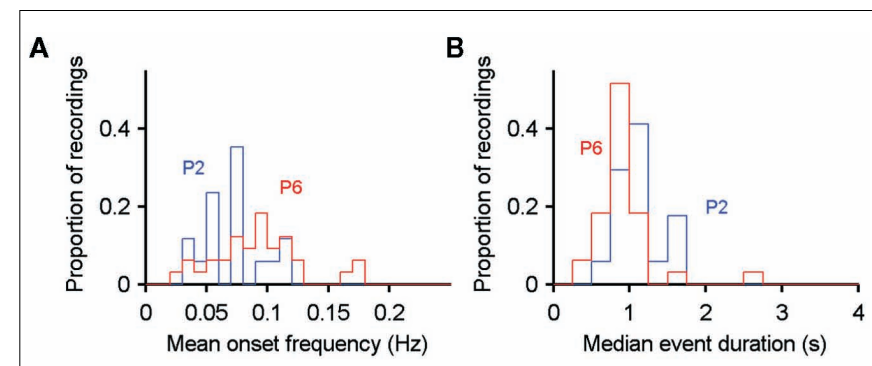

C
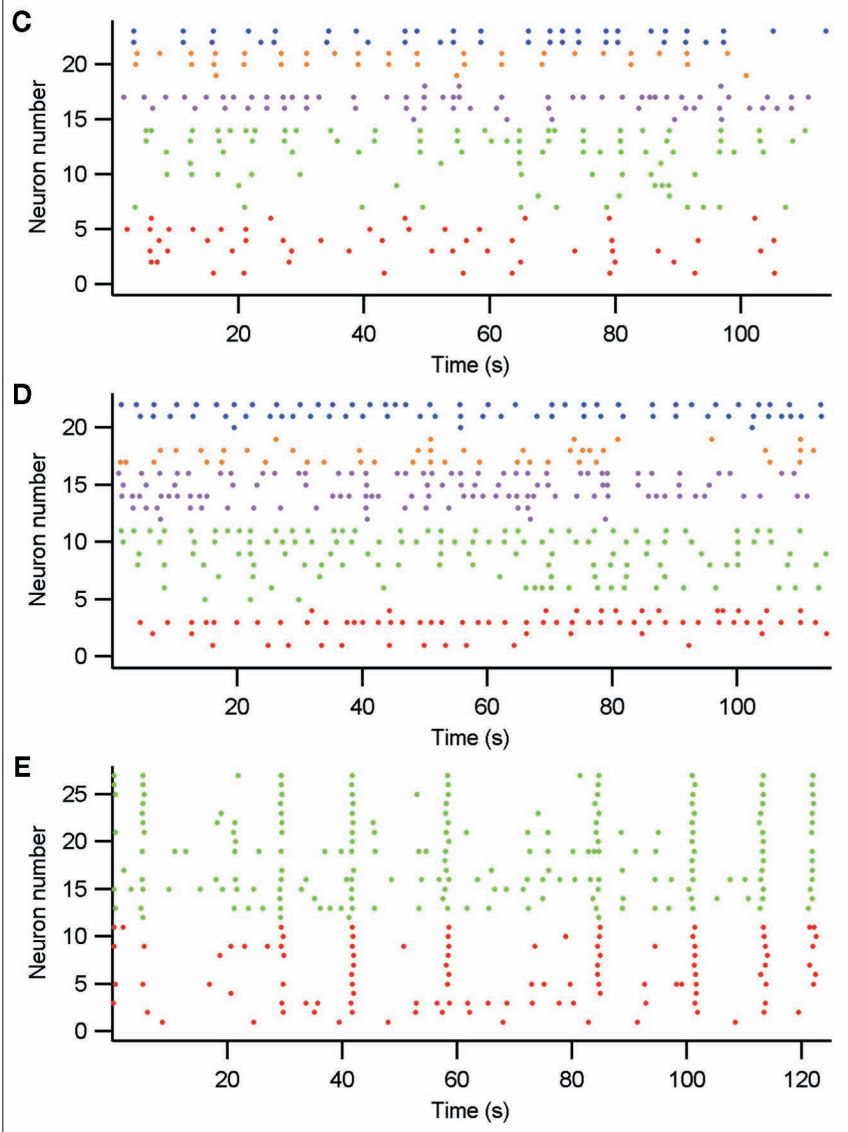

FIGURE 10 | Comparison of intrinsically (P2-P3) and synaptically (P5-P7) driven immature spontaneous $\mathrm{Ca}^{2+}$ activity. $(\mathbf{A}, \mathrm{B})$ Distributions of each recording's mean event frequency and median event duration for P2-P3 (P2) and P5-P7 (P6). (C,D) Example recordings at P2 (C) and P6 (D) with significant neural ensemble structure; both contain five groups. (E) Neural ensembles within GDP-driven network-wide synchronization at P6. In (C-E), neuron activity is color-coded by ensemble membership, as determined by the algorithm of Humphries (2011) - Section "Materials and Methods."

pups. The total distance pups traveled along straight line segments underwent a marked increase from P3 to P6 $(0.2 \pm 0.1 \mathrm{~cm}$, $n=56)$ to $\mathrm{P} 9-\mathrm{P} 10(7.9 \pm 1.6 \mathrm{~cm}, n=28 ; p=0.0002$, one way ANOVA test). By P12 pups traversed relatively large distances $\left(28.9 \pm 3.5 \mathrm{~cm}, n=14 ; p=1 \times 10^{-12}\right.$ compared to P9-P10; one way ANOVA test; Figures 11F,G, bottom). Thus, spontaneous displacement with the ventral surface of the body held above the floor was first observed in P9-P10 mouse pups, in parallel with the chronology of MSN silencing. 


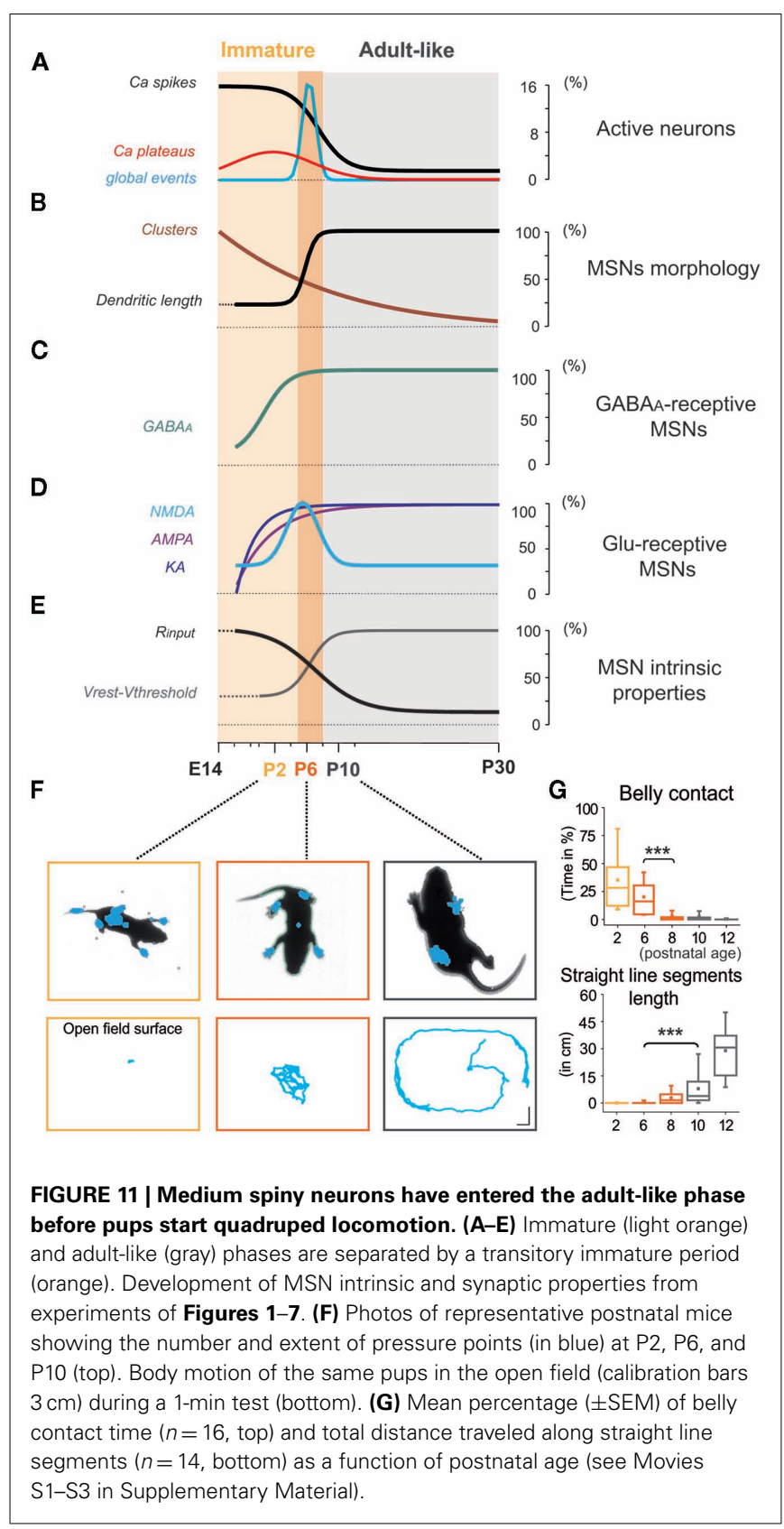

\section{DISCUSSION}

Our results show that MSNs, the dominant neuronal population of the striatum, generate immature patterns of activity at embryonic and early postnatal stages that are reminiscent of the patterns observed in developing cortical structures (Garaschuk et al., 2000; Corlew et al., 2004; Allene et al., 2008). This confirms the similarity between developmental activities of networks independently of their neuronal structure and final function (Ben-Ari, 2001). In the middle of the second postnatal week, MSNs shift to an adultlike pattern characterized by little activity in vitro (Carrillo-Reid et al., 2008), just before pups lift their body and begin to walk. Underlying this transition is a change in the fundamental characteristics of MSNs (Figure 11). This suggests that the development of MSNs and striatal network activity parallels the development of locomotor structures and pathways (Grillner et al., 2005).

Two features of immature MSNs emerge as central players in this progression. (i) Intrinsic voltage-gated $\mathrm{Ca}^{2+}$ currents: we propose that the reduced $\mathrm{K}^{+}$currents and the consequent depolarized resting membrane potential allow spontaneous opening of $\mathrm{N}$ and L-type voltage-gated $\mathrm{Ca}^{2+}$ channels, then quieted near $\mathrm{P} 10$ by resting membrane potential hyperpolarization and/or developmental changes of $\mathrm{Ca}^{2+}$ channel properties; (ii) The transient NR2C/Dmediated cationic current: the expression of long lasting NMDA EPSCs mediated by the NR2C/D receptor subunit is a general feature of different developing brain structures (Monyer et al., 1994; Nansen et al., 2000; Logan et al., 2007; Dravid et al., 2008). NMDA receptor-mediated EPSCs are conspicuous in cortico-striatal neurons as early as P2 (see Hurst et al., 2001) for contradictory results). Using a dose of PPDA $(100 \mathrm{nM})$ that preferentially antagonizes NR2C/D subunits $\left(K_{D}=0.096\right.$ and $0.130 \mu \mathrm{M}$, respectively; Traynelis et al., 2010), we demonstrate that the window of operation of NR2C/D-mediated events is highly restricted to P5-P8 (Dunah et al., 1996). Therefore, as in other brain structures, immature neurons first generate long lasting synapse-driven patterns of activity that include large NMDA receptor driven currents. These currents, together with voltage-gated $\mathrm{Ca}^{2+}$ currents, trigger the large calcium fluxes needed for a wide range of essential developmental functions including neuronal growth, synapse formation, and the formation of neuronal ensembles (Spitzer, 2006). Indeed, we demonstrated that during this P5-P8 window, network-wide changes in calcium event statistics correlated with the reliable formation of neural ensembles.

Our observations also provide interesting insights concerning the generation of GDPs that have been observed in a wide range of brain networks but investigated primarily in cortical structures (Ben-Ari et al., 2007). GDPs are generated both by depolarizing GABAergic and glutamatergic notably NMDA receptors-mediated currents. The striatum is an interesting site to investigate the debated role of glutamate in GDPs generation because it has in contrast with other investigated structures no internal glutamatergic neurons. Clearly, the maturation of the glutamatergic cortico-striatal inputs is instrumental in the emergence of GDPs and particularly the long lasting NR2C/D component.

Adesnik et al. (2008) suggested that modest activity through NMDA receptors prevents the constitutive trafficking of AMPA receptors to the postsynaptic density via an LTD type mechanism. This ensures that synapses become functional only after strong or correlated activity, when enough calcium entry through these NMDA receptors overrides the inhibitory pathway and drives AMPA receptor insertion. This surge is provided by bursts of action potentials during GDPs and NMDA-mediated corticostriatal EPSPs as shown here. From this perspective the elimination of the long lasting NR2C/D component in cortico-striatal EPSPs would constitute a gating device to induce the expression of AMPAergic currents in MSNs.

Therefore, our results suggest an intrinsic program that switches MSN activity from an immature low threshold activation state to a high threshold state in the adult with a low activity profile during resting conditions, coincident with the emergence of locomotion. In a more conceptual frame, in addition to ubiquitous 
developmental patterns of activity, there would be a superimposed sequence, unique to each brain structure, which takes over at an appropriate time to enable the generation of patterns required for specific functions. The adult-like state described here is accompanied by several additional factors including the development of the dendritic arbor and spines of MSNs and the increased density of asymmetric glutamatergic synapses (Tepper et al., 1998; Belleau and Warren, 2000), a second wave of nigro-striatal dopaminergic innervation (Moon and Herkenham, 1984), the development of thalamo-cortical loops, and sensori-motor cortex (Gianino et al., 1999; Vinay et al., 2002; Allene et al., 2008; Evrard and Ropert, 2009). It is also accompanied functionally by a dopamine- and D2 receptor-dependent decrease in the efficacy of glutamatergic transmission that takes place in vivo during weeks 2-3 of postnatal development and is a consequence of a number of physiological changes in the maturing striatum (Choi and Lovinger, 1997; Tang et al., 2001). Also, comparison of the present data with that obtained in rodents lacking dopaminergic substantia nigra neurons (pitx $3^{-/-}$mice for example, Smidt et al., 2004), will allow understanding of the early role of endogenous dopamine on the development of the striatal network (Ohtani et al., 2003; Goffin et al., 2010).

Finally, present observations may be of clinical relevance because adult MSNs from the R6/2 rodent model of Huntington's

\section{REFERENCES}

Adesnik, H., Li, G., During, M. J., Pleasure, S. J., and Nicoll, R. A. (2008). NMDA receptors inhibit synapse unsilencing during brain development. Proc. Natl. Acad. Sci. U.S.A. 105, 5597-5602.

Allene, C., Cattani, A., Ackman, J. B., Bonifazi, P., Aniksztejn, L., Ben-Ari, Y., and Cossart, R. (2008). Sequential generation of two distinct synapsedriven network patterns in developing neocortex. J. Neurosci. 28, 12851-12863.

Ariano, M. A., Cepeda, C., Calvert, C. R., Flores-Hernandez, J., HernandezEcheagaray, E., Klapstein, G. J., Chandler, S. H., Aronin, N., DiFiglia, M., and Levine, M. S. (2005). Striatal potassium channel dysfunction in Huntington's disease transgenic mice. J. Neurophysiol. 93, 2565-2574.

Belleau, M. L., and Warren, R. A. (2000). Postnatal development of electrophysiological properties of nucleus accumbens neurons. J. Neurophysiol. 84, 2204-2216.

Ben-Ari, Y. (2001). Developing networks play a similar melody. Trends Neurosci. 24, 353-360.

Ben-Ari, Y. (2002). Excitatory actions of gaba during development: the nature of the nurture. Nat. Rev. Neurosci. 3, 728-739.

Ben-Ari, Y., Gaiarsa, J. L., Tyzio, R., and Khazipov, R. (2007). GABA: a pioneer transmitter that excites

disease resemble immature MSNs described here in several respects, including an increased input resistance, depolarized resting membrane potential, low level of inwardly and outwardly rectifying $\mathrm{K}^{+}$currents (Ariano et al., 2005), increased sensitivity to NMDA receptor activation (Cepeda et al., 2001) and decreased sensitivity of NMDA receptors to $\mathrm{Mg}^{2+}$ block (Starling et al., 2005).

\section{ACKNOWLEDGMENTS}

The RCE:LoxP reporter strain was a gift of the Fishell laboratory. We thank R. Cossart, D. Aronov, and P. Bonifazi who developed the analysis method of the imaging data, J. Gallego for the use of the motricity platform facility and Y. Ben Ari for helpful discussions. This work was supported by grants from Institut National de La Santé et de la Recherche Médicale (INSERM), Fédération pour la Rechercher sur le Cerveau (FRC), Association Française contre les Myophaties (AFM), and Fondation Motrice. Nathalie Dehorter held a studentship from Région Provence Alpes Côte d'Azur, Neuroservice (Dir B. Buisson), and Association France Parkinson.

\section{SUPPLEMENTARY MATERIAL}

The Supplementary Material for this article can be found online at http://www.frontiersin.org/cellular_neuroscience/10.3389/fncel. 2011.00024/abstract

synapses. Proc. Natl. Acad. Sci. U.S.A. 94, 2665-2670.

Corlew, R., Bosma, M. M., and Moody, W. J. (2004). Spontaneous, synchronous electrical activity in neonatal mouse cortical neurones. J. Physiol. 560, 377-390.

Crepel, V., Aronov, D., Jorquera, I., Represa, A., Ben-Ari, Y., and Cossart, R. (2007). A parturition-associated nonsynaptic coherent activity pattern in the developing hippocampus. Neuron 54, 105-120.

Deacon, T. W., Pakzaban, P., and Isacson, O. (1994). The lateral ganglionic eminence is the origin of cells committed to striatal phenotypes: neural transplantation and developmental evidence. Brain Res. 668, 211-219.

Dehorter, N., Guigoni, C., Lopez, C., Hirsch, J., Eusebio, A., Ben-Ari, Y., and Hammond, C. (2009). Dopamine-deprived striatal GABAergic interneurons burst and generate repetitive gigantic IPSCs in medium spiny neurons. $J$. Neurosci. 29, 7776-7787.

Dravid, S. M., Prakash, A., and Traynelis, S. F. (2008). Activation of recombinant NR1/NR2C NMDA receptors. J. Physiol. 586, 4425-4439.

Dunah, A. W., Yasuda, R. P., Wang, Y. H., Luo, J., vila-Garcia, M., Gbadegesin, M., Vicini, S., and Wolfe, B. B. (1996). Regional and ontogenic expression of the NMDA receptor subunit NR2D protein in rat brain using a subunit-specific antibody. $J$. Neurochem. 67, 2335-2345.

Epsztein, J., Represa, A., Jorquera, I., Ben-Ari, Y., and Crepel, V. (2005). Recurrent mossy fibers establish aberrant kainate receptoroperated synapses on granule cells from epileptic rats. J. Neurosci. 25, 8229-8239.

Evrard, A., and Ropert, N. (2009). Early development of the thalamic inhibitory feedback loop in the primary somatosensory system of the newborn mice. J. Neurosci. 29, 9930-9940.

Feng, B., Tse, H. W., Skifter, D. A., Morley, R., Jane, D. E., and Monaghan, D. T. (2004). Structure-activity analysis of a novel NR2C/NR2D-preferring NMDA receptor antagonist: 1-(phenanthrene-2-carbonyl) piperazine-2,3-dicarboxylic acid. Br. J. Pharmacol. 141, 508-516.

Garaschuk, O., Linn, J., Eilers, J., and Konnerth, A. (2000). Large-scale oscillatory calcium waves in the immature cortex. Nat. Neurosci. 3, 452-459.

Gianino, S., Stein, S. A., Li, H., Lu, X., Biesiada, E., Ulas, J., and Xu, X. M. (1999). Postnatal growth of corticospinal axons in the spinal cord of developing mice. Brain Res. Dev. Brain Res. 112, 189-204. 
Goffin, D., Ali, A. B., Rampersaud, N., Harkavyi, A., Fuchs, C., Whitton, P. S., Nairn, A. C., and Jovanovic, J. N. (2010). Dopamine-dependent tuning of striatal inhibitory synaptogenesis. J. Neurosci. 30, 2935-2950.

Grillner, S., Hellgren, J., Menard, A., Saitoh, K., and Wikstrom, M. A. (2005). Mechanisms for selection of basic motor programs-roles for the striatum and pallidum. Trends Neurosci. 28, 364-370.

Groc, L., Gustafsson, B., and Hanse, E. (2002). Spontaneous unitary synaptic activity in CAl pyramidal neurons during early postnatal development: constant contribution of AMPA and NMDA receptors. J. Neurosci. 22, 5552-5562.

Han, J. Y. (2005). "Low-cost multitouch sensing through frustrated total internal reflection," in Proceedings of the 18th Annual ACM Symposium on User Interface Software and Technology - UIST (New York, NY: ACM Press), 115-118.

Huberman, A. D., Feller, M. B., and Chapman, B. (2008). Mechanisms underlying development of visual maps and receptive fields. Annu. Rev. Neurosci. 31, 479-509.

Humphries, M. D. (2011). Spike-train communities: finding groups of similar spike trains. J. Neurosci. 31, 2321-2336.

Hurst, R. S., Cepeda, C., Shumate, L. W., and Levine, M. S. (2001). Delayed postnatal development of NMDA receptor function in medium-sized neurons of the rat striatum. Dev. Neurosci. 23, 122-134.

Koos, T., and Tepper, J. M. (1999). Inhibitory control of neostriatal projection neurons by GABAergic interneurons. Nat. Neurosci. 2, 467-472.

Logan, S. M., Partridge, J. G., Matta, J. A., Buonanno, A., and Vicini, S. (2007). Long-lasting NMDA receptor-mediated EPSCs in mouse striatal medium spiny neurons. $J$. Neurophysiol. 98, 2693-2704.

Misgeld, U., Wagner, A., and Ohno, T. (1982). Depolarizing IPSPs and Depolarization by GABA of rat neostriatum cells in vitro. Exp. Brain Res. 45, 108-114.

Monyer, H., Burnashev, N., Laurie, D. J., Sakmann, B., and Seeburg, P. H. (1994). Developmental and regional expression in the rat brain and functional properties of four NMDA receptors. Neuron 12, 529-540.

Moon, E. S., and Herkenham, M. (1984). Comparative development of striatal opiate receptors and dopamine revealed by autoradiography and histofluorescence. Brain Res. 305, 27-42.

Nansen, E. A., Jokel, E. S., Lobo, M. K., Micevych, P. E., Ariano, M. A., and Levine, M. S. (2000). Striatal ionotropic glutamate receptor ontogeny in the rat. Dev. Neurosci. $22,329-340$.

Nimmerjahn, A., Kirchhoff, F., Kerr, J. N., and Helmchen, F. (2004). Sulforhodamine 101 as a specific marker of astroglia in the neocortex in vivo. Nat. Methods 1, 31-37.

Nobrega-Pereira, S., Kessaris, N., Du, T., Kimura, S., Anderson, S. A., and Marin, O. (2008). Postmitotic Nkx2-1 controls the migration of telencephalic interneurons by direct repression of guidance receptors. Neuron 59, 733-745.

Ohtani, N., Goto, T., Waeber, C., and Bhide, P. G. (2003). Dopamine modulates cell cycle in the lateral ganglionic eminence. J. Neurosci. 23, 2840-2850.

Olsson, M., Bjorklund, A., and Campbell, K. (1998). Early specification of striatal projection neurons and interneuronal subtypes in the lateral and medial ganglionic eminence. Neuroscience 84, 867-876.

Shen, W., Tian, X., Day, M., Ulrich, S., Tkatch, T., Nathanson, N. M., and Surmeier, D. J. (2007). Cholinergic modulation of Kir2 channels selectively elevates dendritic excitability in striatopallidal neurons. Nat. Neurosci. 10, 1458-1466.

Smidt, M. P., Smits, S. M., Bouwmeester, H., Hamers, F. P., van der Linden, A. J., Hellemons, A. J., Graw, J., and Burbach, J. P. (2004). Early developmental failure of substantia nigra dopamine neurons in mice lacking the homeodomain gene Pitx3. Development 131, 1145-1155.

Sousa, V. H., Miyoshi, G., HjerlingLeffler, J., Karayannis, T., and Fishell, G. (2009). Characterization of Nkx6-2-derived neocortical interneuron lineages. Cereb. Cortex 19(Suppl. 1), i1-i10.

Spitzer, N. C. (2006). Electrical activity in early neuronal development. Nature 444, 707-712.

Starling, A. J., Andre, V. M., Cepeda, C., de, L. M., Chandler, S. H., and Levine, M. S. (2005). Alterations in N-methyl-D-aspartate receptor sensitivity and magnesium blockade occur early in development in the R6/2 mouse model of Huntington's disease. J. Neurosci. Res. 82, 377-386.

Tang, K., Low, M. J., Grandy, D. K., and Lovinger, D. M. (2001) Dopamine-dependent synaptic plasticity in striatum during in vivo development. Proc. Natl. Acad. Sci. U.S.A. 98, 1255-1260.

Tepper, J. M., Koos, T., and Wilson, C. J. (2004). GABAergic microcircuits in the neostriatum. Trends Neurosci. 27, 662-669.

Tepper, J. M., Sharpe, N. A., Koos, T. Z., and Trent, F. (1998). Postnatal development of the rat neostriatum: electrophysiological, light- and electronmicroscopic studies. Dev. Neurosci. 20, 125-145.

Todd, K. L., Kristan, W. B. Jr., and French, K. A. (2010). Gap junction expression is required for normal chemical synapse formation. $J$. Neurosci. 30, 15277-15285.

Traynelis, S. F., Wollmuth, L. P., McBain, C. J., Menniti, F. S., Vance, K. M., Ogden, K. K., Hansen, K. B., Yuan, H., Myers, S. J., Dingledine, R., and Sibley, D. (2010). Glutamate receptor ion channels: structure, regulation, and function. Pharmacol. Rev. 62, 405-496.

Tyzio, R., Ivanov, A., Bernard, C. Holmes, G. L., Ben-Ari, Y., and Khazipov, R. (2003). Membrane potential of $\mathrm{CA} 3$ hippocampal pyramidal cells during postnatal development. J. Neurophysiol. 90, 2964-2972.

Van Der Kooy, D., and Fishell, G. (1987). Neuronal birthdate underlies the development of striatal compartments. Brain Res. 401, 155-161.

Venance, L., Glowinski, J., and Giaume, C. (2004). Electrical and chemical transmission between striatal GABAergic output neurones in rat brain slices. J. Physiol. 559, 215-230.

Vinay, L., Brocard, F., Clarac, F., Norreel, J. C., Pearlstein, E., and Pflieger, J. F. (2002). Development of posture and locomotion: an interplay of endogenously generated activities and neurotrophic actions by descending pathways. Brain Res. Brain Res. Rev. 40, 118-129.

Wilson, C. J., and Kawaguchi, Y. (1996). The origins of two-state spontaneous membrane potential fluctuations of neostriatal spiny neurons. $J$. Neurosci. 16, 2397-2410.

Conflict of Interest Statement: The authors declare that the research was conducted in the absence of any commercial or financial relationships that could be construed as a potential conflict of interest.

Received: 14 September 2011; paper pending published: 06 October 2011; accepted: 21 October 2011; published online: 21 November 2011.

Citation: Dehorter N, Michel FJ, Marissal T, Rotrou Y, Matrot B, Lopez $C$, Humphries $M D$ and Hammond $C$ (2011) Onset of pup locomotion coincides with loss of NR2C/D-mediated cortico-striatal EPSCs and dampening of striatal network immature activity. Front. Cell. Neurosci. 5:24. doi: 10.3389/fncel.2011.00024

Copyright (c) 2011 Dehorter, Michel, Marissal, Rotrou, Matrot, Lopez, Humphries and Hammond. This is an open-access article subject to a nonexclusive license between the authors and Frontiers Media SA, which permits use, distribution and reproduction in other forums, provided the original authors and source are credited and other Frontiers conditions are complied with. 